Article

\title{
Responses of HSP70 Gene to Vibrio parahaemolyticus Infection and Thermal Stress and Its Transcriptional Regulation Analysis in Haliotis diversicolor
}

\author{
Zhiqiang Fang ${ }^{1}$, Yulong Sun ${ }^{2}$, Xin Zhang ${ }^{2}$, Guodong Wang ${ }^{1}$, Yuting Li $^{1}$, Yilei Wang ${ }^{1, *}$ \\ and Ziping Zhang ${ }^{2, *}$ \\ 1 Key Laboratory of Healthy Mariculture for the East China Sea, Ministry of Agriculture, Fisheries College, \\ Jimei University, Xiamen 361021, China; zqfang0721@163.com (Z.F.); gdwang@jmu.edu.cn (G.W.); \\ 13123395315@163.com (Y.L.) \\ 2 College of Animal Science, Fujian Agriculture and Forestry University, Fuzhou 350002, China; \\ ylsun1@126.com (Y.S.); zhangxinexe@126.com (X.Z.) \\ * Correspondence: ylwang@jmu.edu.cn (Y.W.); zhangziping@fafu.edu.com (Z.Z.); \\ Tel.: +86-592-618-6780 (Y.W.)
}

Received: 12 November 2018; Accepted: 17 December 2018; Published: 3 January 2019

\begin{abstract}
Heat-shock protein 70 (HSP70) is a molecular chaperone that plays critical roles in cell protein folding and metabolism, which helps to protect cells from unfavorable environmental stress. Haliotis diversicolor is one of the most important economic breeding species in the coastal provinces of south China. To date, the expression and transcriptional regulation of HSP70 in Haliotis diversicolor (HdHSP70) has not been well characterized. In this study, the expression levels of HdHSP70 gene in different tissues and different stress conditions were detected. The results showed that the HdHSP70 gene was ubiquitously expressed in sampled tissues and was the highest in hepatopancreas, followed by hemocytes. In hepatopancreas and hemocytes, the HdHSP70 gene was significantly up-regulated by Vibrio parahaemolyticus infection, thermal stress, and combined stress (Vibrio parahaemolyticus infection and thermal stress combination), indicating that $H d \mathrm{HSP} 70$ is involved in the stress response and the regulation of innate immunity. Furthermore, a $2383 \mathrm{bp}$ of $5^{\prime}$-flanking region sequence of the HdHSP70 gene was cloned, and it contains a presumed core promoter region, a CpG island, a (TG) ${ }_{39}$ simple sequence repeat (SSR), and many potential transcription factor binding sites. The activity of HdHSP70 promoter was evaluated by driving the expression of luciferase gene in HEK293FT cells. A series of experimental results indicated that the core promoter region is located between $-189 \mathrm{bp}$ and $+46 \mathrm{bp}$, and high-temperature stress can increase the activity of HdHSP70 promoter. Sequence-consecutive deletions of the luciferase reporter gene in HEK293FT cells revealed two possible promoter activity regions. To further identify the binding site of the key transcription factor in the two regions, two expression vectors with site-directed mutation were constructed. The results showed that the transcriptional activity of NF-1 site-directed mutation was significantly increased $(p<0.05)$, whereas the transcriptional activity of NF- $\mathrm{kB}$ site-directed mutation was significantly reduced. These results suggest that NF-1 and NF- $\mathrm{kB}$ may be two important transcription factors that regulate the expression of $H d H S P 70$ gene.
\end{abstract}

Keywords: HSP70; thermal; Vibrio parahaemolyticus; transcriptional regulation; Haliotis diversicolor

\section{Introduction}

Small abalone Haliotis diversicolor belongs to Mollusca, Gastropoda, Prosobranchia, Archaeogastropoda, Haliotidae and Haliotis. Due to its high nutritional and medicinal values, $H$. diversicolor has become one of the most important economic breeding species in the coastal provinces 
of south China. However, the deterioration of the living environment, such as high temperature, hypoxia and infection of pathogenic bacteria, has led to a sharp decline in the resources and aquaculture of $H$. diversicolor [1,2]. Temperature and pathogenic bacteria are the key factors affecting the growth and health of the abalone [3,4]. The optimum growth temperature of the abalone is $22-28^{\circ} \mathrm{C}$. In a study it was shown that, when the water temperature elevated from $28{ }^{\circ} \mathrm{C}$ to $32{ }^{\circ} \mathrm{C}$, the phenol oxidase activity and phagocytic activities were negatively affected in the animals, indicating the importance of the environmental factors, mainly temperature, on the innate immune system regulation of the abalones [5]. Similarly, Vibrio parahaemolyticus has been described as the major pathogen that significantly affects the culture of $H$. diversicolor by invading the innate immune system of the cultured animals $[5,6]$. Therefore, understanding the mechanism behind the adverse effects of environmental factors, mainly elevated temperature, and pathogen invasion, on the innate immune system of abalone is of high importance.

The innate immune system is the body's first line in which the relevant cells non-specifically recognize and act on the pathogen to protect against pathogen infection [7]. Heat-shock proteins (HSPs) are a group of highly conserved chaperone proteins expressed by the cell that respond to unfavorable environmental change [8]. HSPs have been found in almost all organisms, from bacteria to humans. Various stimuli including heat stress damage can induce the synthesis of HSPs, which increase the adaptability of the organism to the environmental stresses [9]. The HSPs buffer this environmental variation and are therefore important factors for the maintenance of homeostasis across environmental regimes [10]. HSPs are also a potentially important modulator of immune responses against many bacterial infections [11]. Therefore, it is necessary to understand the function and regulation mechanism of heat-shock protein. According to the sequence similarity and molecular size, six major HSP families have been identified, namely HSP110, HSP90, HSP70, HSP60, HSP40, and the small HSPs [12].

In the HSP families, HSP70 has been widely studied as a biomarker [13]. The amino acid sequence homology of HSP70 family is highly conserved [14], and their molecular weights are around $70 \mathrm{KDa}$. HSP70 family can be roughly divided into two types: structural HSP70 (heat-shock cognate protein 70, HSC70), and inducible HSP70 (heat-shock inducible protein 70, HSP70) $[15,16]$. HSC70 was expressed in all tested cells, but usually there was no significant change in expression levels under stress conditions [17]. HSP70 was generally expressed in small amounts in normal cells, but its expression level rapidly increased under stress conditions [18,19]. HSP70 has the function of resisting oxidation, participating in cellular immunity, and enhancing cell stress tolerance [20]. HSP70 and HSC70 are not only expressed in mammals but also in non-mammals, such as fish [21] and mollusks [22,23]. Many studies have proved that HSP70 exhibits physiological and ecological importance in response to pathogen infection and environmental stress. For example, in fish, heat shock was the most effective stress stimuli to induce HSP70 response compared to other stressors including hypoxia and air exposure [24]. In mollusks, HSP70 transcripts increased significantly after acute heat stress $[25,26]$. Up-regulation of HSP70 was observed after V. parahaemolyticus infection in adult bay scallops Argopecten irradians [27]. The expression of HSP70 in the zebra mussel Dreissena polymorpha showed a time-dependent increase after lipopolysaccharide (LPS) stimulation [28]. However, so far, the expression of HSP70 gene in H. diversicolor (named HdHSP70) has rarely been reported.

Gene expression in eukaryotes is the result of interaction between transcription factors and cis-acting elements. In addition, the promoter is an important response element that regulates gene expression and determines gene activity. Therefore, the promoter is always a research hotspot [29]. The promoter is located near the transcription start sites of structural gene and binds directly to RNA polymerase and its transcription factors to determine whether gene transcription is activated. The transcription factors of eukaryotes have specific DNA binding domain, transcriptional activation domain and regulatory domain, which bind to specific promoter elements on the DNA sequence under the action of the transcription activator [30]; therefore, it plays an important role in regulating the transcription of target genes [31-33]. Oda et al. demonstrated that the promoter of Medaka HSP70 gene is an inducible promoter, which can induce the expression of foreign genes in vivo, in vitro, 
and during early embryo development of the transgenic Medaka [34]. The regulatory sequences of eukaryotic genes usually contain binding sites for multiple transcription factors and provide a basis for combinatorial interactions among different factors. Stephanou et al. found that transcriptional activator (STAT-3) enhances the promoter activity of HSP70 in HepG2 hepatoma cells, and observed an additive effect on the increase in HSP70 promoter activity when STAT-1 and HSF-1 were binding each other [35]. Chen et al. found that deletion of transcription factor binding sites rich in AT sequence enhances the luciferase activity of the HSP70 gene of the fly Liriomyza sativae, speculating the element inhibits transcription of the gene [36]. Sistonen et al. found that two members of the human HSF family, HSF1 and HSF2, can be used as transcriptional activators of heat-shock gene expression and synergistically induce HSP70 gene transcription [37]. However, the transcriptional regulation of HdHSP70 in H. diversicolor has not been well characterized.

Regarding several immune-related genes of $H$. diversicolor and their activation under different environmental stress and bacterial infections, there have been relevant studies in our laboratory. For example, Zhang et al. reported that the mRNA expression levels in either gills or hemocytes of SalakB, SaAkirin2 and AbNF- $k B$ significantly up-regulated post thermal stress and the injection of $V$. parahaemolyticus [38]. Huang et al. have confirmed that the expression level of the heat-shock-responsive genes were up-regulated under thermal and hypoxia stresses [39]. Most of these experiments explored the expression of genes at less than $96 \mathrm{~h}$ in different environmental emergency situations. Recently, Sun et al. found that the mRNA expression of the PI3K-AKT was significantly down-regulated after the $V$. parahaemolyticus stimulation with environment stimulation (thermal, hypoxia, and thermal and hypoxia) in gills, hemocytes, and hepatopancreas after more than $96 \mathrm{~h} \mathrm{[40].}$ Therefore, this project aims to investigate (1) the expression of HdHSP70 gene under V. parahaemolyticus, thermal stress, and their combined stress for more than $96 \mathrm{~h}$, and (2) the promotor structure and transcriptional regulation of $H S P 70$ gene in $H$. diversicolor. These studies can provide new insights into the immune mechanisms of $H$. diversicolor.

\section{Results}

\subsection{Tissue Expression of the HdHSP70 Gene}

The expression level of $H d H S P 70$ in different tissues was performed by quantitative real-time polymerase chain reaction (qRT-PCR). HdHSP70 was expressed in all examined tissues with the significantly higher expression level being in hepatopancreas $(\mathrm{Hp})(p<0.05)$, followed by hemocytes $(\mathrm{He})(p<0.05)$ (Figure 1). Based on the obtained results, Hp and He were set as experimental tissues in different stress groups.

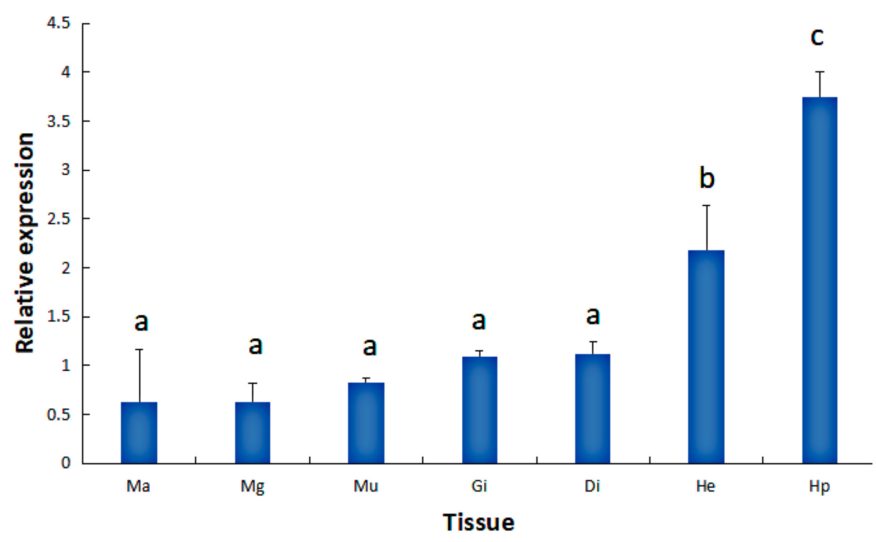

Figure 1. Expression levels of HdHSP70 in different tissues of H. diversicolor. Tissues are mantle (Ma), mucous gland $(\mathrm{Mg})$, muscle $(\mathrm{Mu})$, gills $(\mathrm{Gi})$, digestive tract $(\mathrm{Di})$, hemocytes $(\mathrm{He})$, and hepatopancreas $(\mathrm{Hp}) . \beta$-actin was selected as a reference gene. Values are means \pm SD of biological replicates $(n=6)$. The different letters on the error bars represent significant difference, $p<0.05$. 


\subsection{Expression of the HdHSP70 Gene under Different Stresses}

In the Hp, under normal condition, the expression level of HdHSP70 was significantly higher $(p<0.05)$ in NE group (abalones were injected with $V$. parahaemolyticus after they had been maintained for $96 \mathrm{~h}$ at the normal temperature $\left(25^{\circ} \mathrm{C}\right)$ and then continually being maintained at the normal temperature) than that in NB group (abalones were injected with $0.9 \% \mathrm{NaCl}$ after they had been maintained for $96 \mathrm{~h}$ at the normal temperature $\left(25^{\circ} \mathrm{C}\right)$ and then continually being maintained at the normal temperature) at $24 \mathrm{~h}$, but NE group and NB group were not different at $4 \mathrm{~h}, 12 \mathrm{~h}$, and $48 \mathrm{~h}$. Under the thermal stress condition, the expression level of HdHSP70 was significantly higher $(p<0.05)$ in HE group (abalones were injected with $V$. parahaemolyticus after they had been maintained for $96 \mathrm{~h}$ at the thermal condition $\left(30^{\circ} \mathrm{C}\right)$ and then continually being maintained at the thermal condition) than that in $\mathrm{HB}$ group (abalones were injected with $0.9 \% \mathrm{NaCl}$ after they had been maintained for $96 \mathrm{~h}$ at the thermal condition $\left(30^{\circ} \mathrm{C}\right)$ and then continually being maintained at the thermal condition) at $4 \mathrm{~h}$ and $12 \mathrm{~h}$, but HE group and HB group were not statistically different at $24 \mathrm{~h}$ and $48 \mathrm{~h}$ (Figure 2).

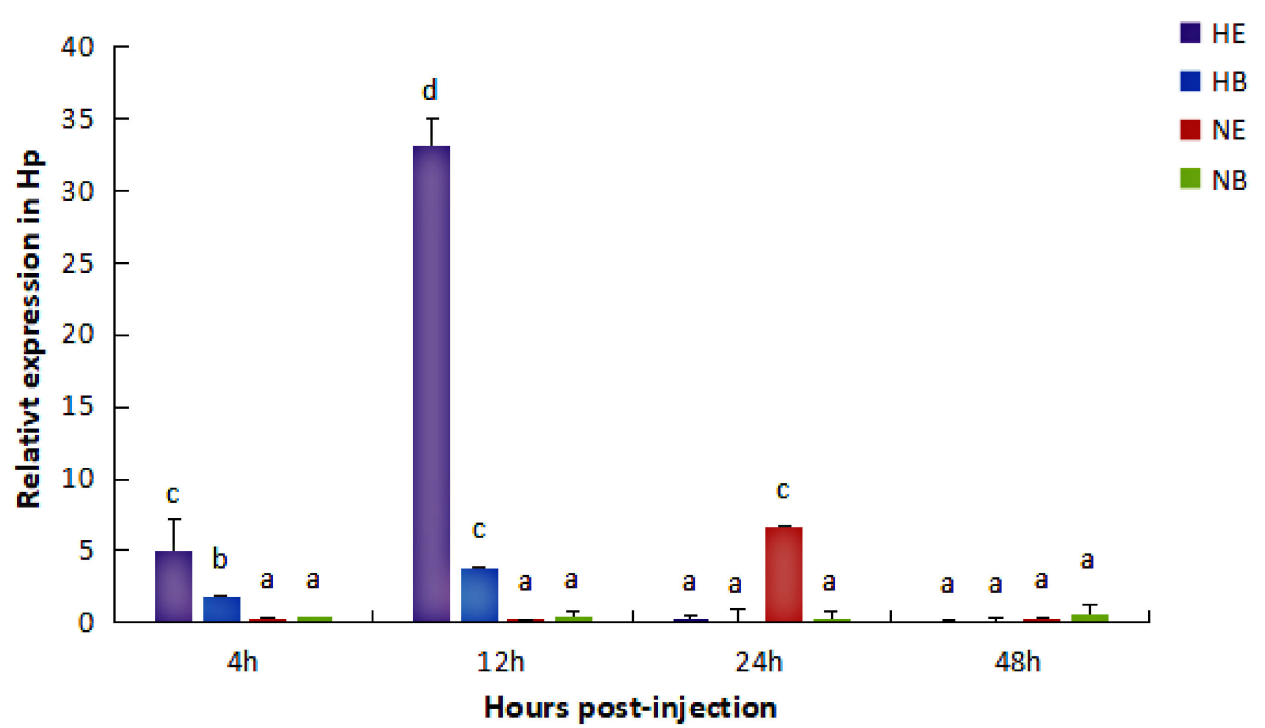

Figure 2. Expression level of HdHSP70 in Hp was detected by qRT-PCR. Abalones were maintained for $96 \mathrm{~h}$ at increased temperature $\left(30^{\circ} \mathrm{C}\right)$ as thermal stress condition, after $96 \mathrm{~h}$ they were injected with $50 \mu \mathrm{L}$ of live $V$. parahaemolyticus $\left(1.1 \times 10^{8} \mathrm{cfu} / \mathrm{mL}\right)(\mathrm{HE})$ or injected with $50 \mu \mathrm{L}$ of $0.9 \% \mathrm{NaCl}(\mathrm{HB})$; Abalones were maintained for $96 \mathrm{~h}$ at normal temperature $\left(25^{\circ} \mathrm{C}\right)$, after $96 \mathrm{~h}$ they were injected with $50 \mu \mathrm{L}$ of live $V$. parahaemolyticus $\left(1.1 \times 10^{8} \mathrm{cfu} / \mathrm{mL}\right)(\mathrm{NE})$ or injected with $50 \mu \mathrm{L}$ of $0.9 \% \mathrm{NaCl}(\mathrm{NB})$; Samples were collected at 4,12, 24 and $48 \mathrm{~h}$ after injection. $\beta$-actin was selected as a reference gene. Values are means \pm SD of biological replicates $(n=6)$. The different letters $(a, b, c$, and $d)$ on the error bars represent significant difference $(p<0.05)$ between challenged and control group. HE: thermal stress and injected $V$. parahaemolyticus, HB: thermal stress and injected $\mathrm{NaCl}$. NE: normal condition and injected V. parahaemolyticus, NB: normal condition and injected $\mathrm{NaCl}$. Hp: hepatopancreas.

In the He, under normal condition, the expression level of HdHSP70 was significantly higher $(p<0.05)$ in NE group than that in NB group at $48 \mathrm{~h}$, but NE group and NB group were not different at $4 \mathrm{~h}, 12 \mathrm{~h}$ and $24 \mathrm{~h}$. Under the thermal stress condition, the expression level of HdHSP70 in HE group was significantly higher $(p<0.05)$ than that in HB group at $12 \mathrm{~h}, 24 \mathrm{~h}$ and $48 \mathrm{~h}$, but HE group and HB group were not statistically different at $4 \mathrm{~h}$ (Figure 3). 


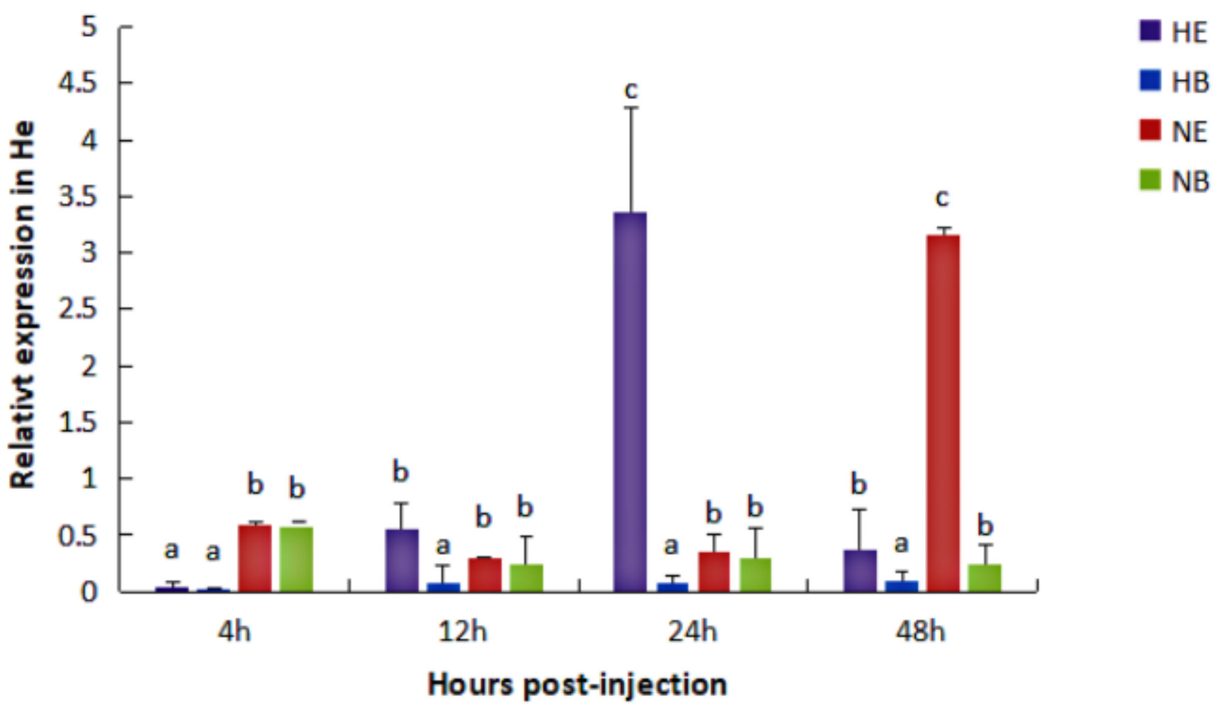

Figure 3. Expression level of HdHSP70 in He was detected by qRT-PCR. Abalones were maintained for $96 \mathrm{~h}$ at increased temperature $\left(30^{\circ} \mathrm{C}\right)$ as thermal stress condition, after $96 \mathrm{~h}$ they were injected with $50 \mu \mathrm{L}$ of live $V$. parahaemolyticus $\left(1.1 \times 10^{8} \mathrm{cfu} / \mathrm{mL}\right)(\mathrm{HE})$ or injected with $50 \mu \mathrm{L}$ of $0.9 \% \mathrm{NaCl}(\mathrm{HB})$; Abalones were maintained for $96 \mathrm{~h}$ at normal temperature $\left(25^{\circ} \mathrm{C}\right)$, after $96 \mathrm{~h}$ they were injected with $50 \mu \mathrm{L}$ of live $V$. parahaemolyticus $\left(1.1 \times 10^{8} \mathrm{cfu} / \mathrm{mL}\right)(\mathrm{NE})$ or injected with $50 \mu \mathrm{L}$ of $0.9 \% \mathrm{NaCl}(\mathrm{NB})$; Samples were collected at 4,12, 24 and $48 \mathrm{~h}$ after injection. $\beta$-actin was selected as a reference gene. Values are means \pm SD of biological replicates $(n=6)$. The different letters $(a, b$, and $c)$ on the error bars represent significant difference $(p<0.05)$ between challenged and control group. HE: thermal stress and injected V. parahaemolyticus, HB: thermal stress and injected $\mathrm{NaCl}$. NE: normal condition and injected $V$. parahaemolyticus, NB: normal condition and injected $\mathrm{NaCl}$. He: hemocytes.

\subsection{The Sequence Analysis of the 5'-Upstream Regulatory Region of HdHSP70 Gene}

The 2383 bp 5'-flanking sequence of HdHSP70 gene was obtained by Tail-PCR and Genome Walker method (Figure 4). The prediction of online software BDGP (Berkeley Drosophila Genome Project) showed that the highest area of the HdHSP70 score (score =1) may be the location of the transcriptional starting site (TSS) of the $5^{\prime}$-regulatory region of the HdHSP70 gene, which is defined as the position of the presumed core promoter, starting from $-40 \mathrm{bp}$ to $+10 \mathrm{bp}$ region, and a typical TATA (a sequence of DNA in the core promoter region of genes) box is located at $-27 \mathrm{bp}$ to $-32 \mathrm{bp}$ ahead of the TSS, but no canonical CAAT box or GC box was found. The potential transcription factor binding sites including NF-1, TBP, C/EBPalpha, OCT-1, GCN4 and NF-kB, etc. and 5 heat-shock elements (HSEs) were found by Alibaba2. In addition, analysis of $5^{\prime}$-flanking sequence revealed that one $(\mathrm{TG})_{39}$ repeat was located between $-962 \mathrm{bp}$ and $-1040 \mathrm{bp}$. CpG island prediction software analysis (GC (a cytosine nucleotide is followed by a guanine nucleotide in the linear sequence of bases along its $5^{\prime} \rightarrow 3^{\prime}$ direction) Percent $>50.0$, Obs. / Exp. $>0.6$, length $>100 \mathrm{bp}$ ) found a CpG island with a length of $228 \mathrm{bp}$ located at $-152 \mathrm{bp}$ to $+76 \mathrm{bp}$. 
ATATATATTACAGTCAGAATTTGAAATTATTCATTTCATGACAAGACAACAAAATTCAGTCATTTCGTGATTCGACTAAAAGAGT -2152 CAGCCATTCGCGTCCGATGTTTTGTCTAACAATAATCAATATACTTCAGTCATTTCACGAAAGTTCACTCAATAACTTGATCTAT -2067 HSE

AAAAGTGTTTTTGTCACTATTATGACAGCGACTGTTTCACTTCAGCTTGGCTTTCAAGCATTAAATACCTGTTTGTTTGACGCTT -1982 GTGTCTAGAACAGCCACACTTCACTAACCCCTATCCACCAAATATATATGACATTTCATGAAATAACTTATGTATATTGTTTCGT -1897 Sp1 ATGATGATCAGAATCATCTAAATTTGACTGACGCCTAATGTACACTCTGACGTCACTTGTCGCTCGTCTACGTCACTAGTTATTG -1812 GCN4

TTTCCACTCAACTTTATCCCTATCACATACTCGGCTTGTCTGTCCTCAAACTTTCCTCAGTAAAGGTCTCAAACTCCTACTTTCC -1727 GATA-1 GATA-1 / C/EBPalpha

TCGGGGTCCCATTTTCACATGATGCTAGGGTCCCGACGGGTCCCGCTACAGTTTCCTAAAATGATTTAAGAGAAGGCAGTAGGAA -1642 $\mathrm{NF}$-kappa $\mathrm{Sp} 1$

AAAGTAACTCTTTTGTAAAGGATGCAGACATTCAGAATATACATGATGGCAGGGTATTTGTACATAACCACGTGTCTATTAGTCT -1557 GCTTAAGAGGAATTTCGAGGCCTACGAGAAACCGCGTGGCCACCACCAGTGAAGTAAAGTGTCGGCCAACTCCTGGCAGACTGGG -1472

$\mathrm{NF}-\mathrm{kappaB}$

GAGCACCATTGATCATGATAGTCAGGTTTTCATTCGTCTGGCATGACATCAGTATGGGGAGTGAGTCTGGTGGTACGTCGTCGAT -1387 CAGACATATCTTCTTCACGAATAGTAACTGGTAGAAACGTCTGTGTAGTGACAGTATGGTGAAAGGGAGGTAATCCACAAAGATA -1302 HSE

CACATTTGAGAAAGGTTTGTTACAAAGAAAGAAGCAAAGCGTACGCAGTTTCCATATATTTAATTTGGAAACCCCTACTTAAGTG -1217 $\mathrm{NF}-\mathrm{kappaB}$

ATCGATCATGTTATTCAATATCCATCAGTTCGAGTCGCACACATGATGCTTGATCAGGGCAGACACCCAACAGAGAAATCACCTA -1132 GTGAAAGGATACAGCCTCATATTACTGACAAGGAACCAAACATACGATAAATGGAAAGATCATTTGATATGATTGGTCAACTCTT -1047 TCCCCAATGTGTGTGTGTGTGTGTGTGTGTGTGTGTGTGTGTGTGTGTGTGTGTGTGTGTGTGTGTGTGTGTGTGTGTGTGTGTG -962 SSR

CCACATGCAACAACGAACTGAAAGGTGTTTTACGTGCACTAAAAGTAGAAGAGTTCACTGAACAGTATAAAGGTGAAAAGAGTGC -877 HSE

TGAAACACAGCTACCACGAATGCATGTGGGTTGTAAATGGAACTAAAATAATCATATCAGTTACGTATGTATAACCCCCAGGTTT -792 TAAAATCACGGGATAACCTTATGCTTGGTTTGTTGTTCGTGCAAAGAAATTGTTCTGAAACACTGTCTGCTCTACGGTGTAACAC -707 ACACAGTCTGTCAACGGTGTTATGCGTGTTTGTTTTCAGTAGAAAATAAAAAAATAAACACAACAAACCCTATCATTTGTCAGTT -622 AGGAGGATACACAAAGGACACCACGACGCAGAAAGATTATTTGTGTTTTCTGTTTTGGTGCCCATACATATGTTTGGATATATGC -537 AGTTTAATCTGATAGAAACATTCACCATTAGGGTTACTATAACAAGTAAATCCTAACAAGTAAGGGCAGGGAGCAGGTGGTGATT -452 GTTACAGGGAGTCGGGGAGGTAAAATATTGTTTAAAGTGGATCAAAGAAAATAATAAATATATTTAGGGAGGTTCATGGAAAATA -367 AAGGGACACTATATGACACCATTCAGGAAATGATTATACTTGACGTTTGATTAAGTTACGAAAACGAAAGCATCTGCTTAAACTG -282 HSE

GAACCCCGTTCTCTGCCGCTCCAGTCAATATCTGAAGAGTTATCTCCCTTGTAGGGATTTTCCCAGTAAAAGACTGGGCGTCTGT -197 $\mathrm{NF}-\mathrm{kappaB}$

CTACCTTAACTAGTAAGGGCGCTTAGCTTGCGTCGTGTACCAATGGGAGGCGTAGTTCATCGTTGTAAGTTGTGACGTCACATTC -112 TAGAGGTTTCCGGAAGATACGCGAGTGTTGTACACAGATCCACGCTGGTGTAGAAACATGGTGTAGGCAAGGCGACTGGTATATA -27 HSE

TATA box

TACAGGCGGTGTGTCAGACCACAGTCATACACCGAGCTGAAAGCTTACACGACTGTATACTACGGAGACACAGGGAAGCAGAGAG 59 Core promoter region

GGAAAGCACACGATCTCTACCTGTTCGATATACTGAAGTGACTTAGTTGAAGAAGATAACATTGAAATTTGCTGAGATTTTGAAG 144

AGAatggcgcctaaaggaaaatcccctgcgatcggcatagacctgggaaca

$\begin{array}{llllllllllllllllllllllll}M & \text { A } & \text { P } & \text { K } & \text { G } & \text { K } & \text { S } & \text { P } & \text { A } & \text { I } & \text { G } & \text { I } & \text { D } & \text { L } & \text { G } & \text { T }\end{array}$

Figure 4. The nucleotide sequence of the $5^{\prime}$-flanking region of HSP70. The potential binding site of the transcription factors were marked with short thin line. Overlapping binding sites are indicated by shading. The predicted core promoter region is shaded, the transcription start site in bold letter, and is located at 1 , and the translation start site (atg) in bolded and underlined. The heat-shock element HSE is marked with a short thick line and SSR with a long thin line. 


\subsection{Activity Analysis of the Promoter Region of HdHSP70 Gene}

To identify the promoter activity of the HdHSP70 gene, the complete $2383 \mathrm{bp} 5^{\prime}$-upstream region was inserted into the pEGFP-1 vector (pEGFP-HSP70) and used to drive expression of the EGFP (Enhanced Green Fluorescent Protein) gene in HEK293FT cells. Under fluorescence microscope, the green fluorescence signal could be detected in pEGFP-HSP70, but it was lower than positive control pEGFP-N1. Meanwhile, no green fluorescence activity was detected in pEGFP-1 (without promoter). The results indicated pEGFP-HSP70 can drive the expression of EGFP protein in HEK239FT cell line (Figure 5).
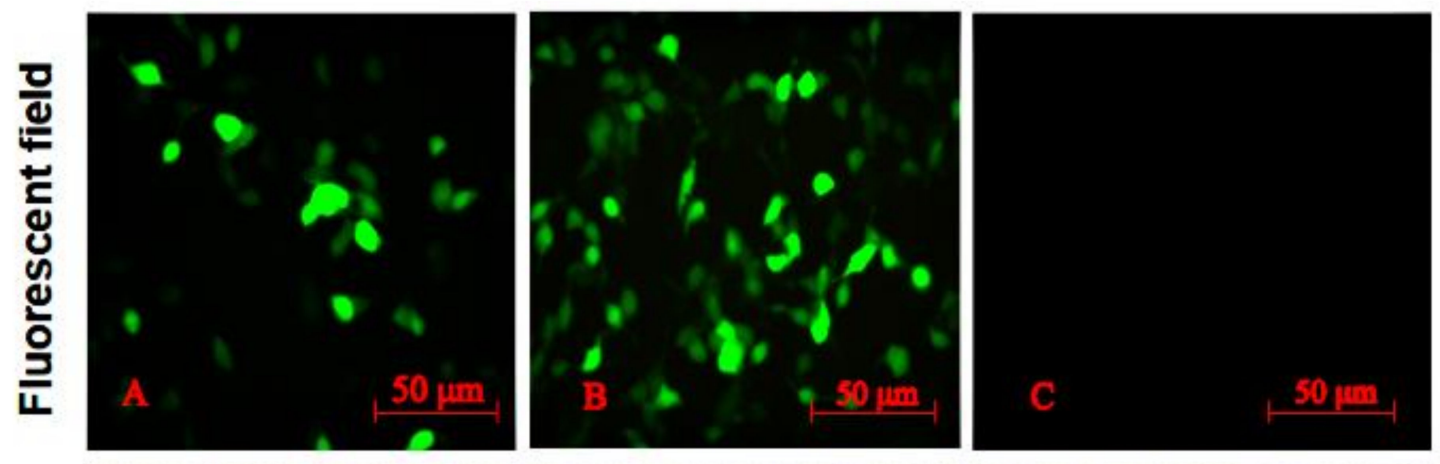

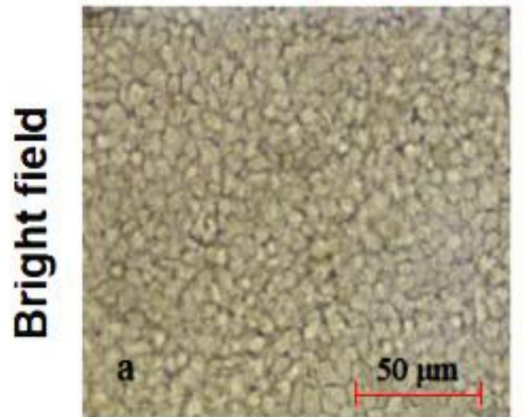

pEGFP-HSP70

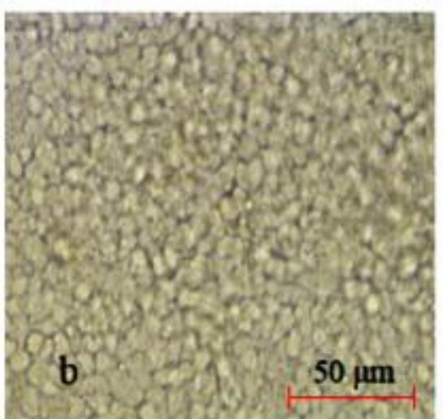

pEGFP-N1

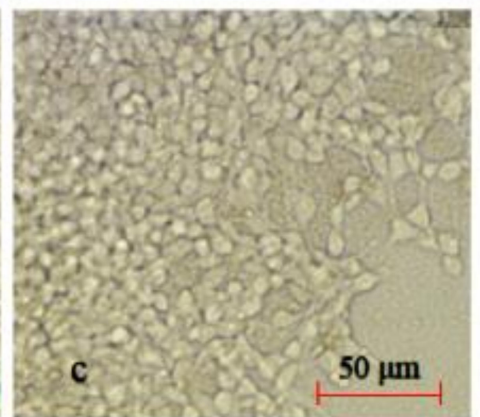

pEGFP-1

Figure 5. The expression of pEGFP-HSP70 in HEK293FT cells. HEK293FT cells were transfected with pEGFP-HSP70 vector that used the HdHSP70 target promoter (A), pEGFP-N1 vector served as a positive control (B), and pEGFP-1 vector used as a negative control (C). After transfected for $24 \mathrm{~h}$, the green fluorescence (EGFP) can be detected in A and B (target plasmid and positive control), but not in C (negative control) under a fluorescence microscope. Fluorescent fields are shown in (A, B and C) and bright fields are observed in $(\mathbf{a}, \mathbf{b}$, and $\mathbf{c})$ separately. Values are means $\pm \mathrm{SD}$ of biological replicates $(n=3)$. Scale Bars were $50 \mu \mathrm{m}$.

To identify the core promoter region of the HdHSP70 gene, two constructed reporter plasmids were prepared and transfected into HEK293FT cells. The plasmid with one from -1974 to +46 containing the core promoter region was named pGL3-70-1 and the other one from -1974 to - 189 lacking the core promoter region was named pGL3-70-1d. The result showed that the luciferase activity of pGL3-70-1 was significantly higher than pGL3-70-1d and negative control (pGL3-Basic, plasmid without inserts) $(p<0.01)$, indicating the core promoter region was located between $-189 \mathrm{bp}$ and $+46 \mathrm{bp}$ (Figure 6). 

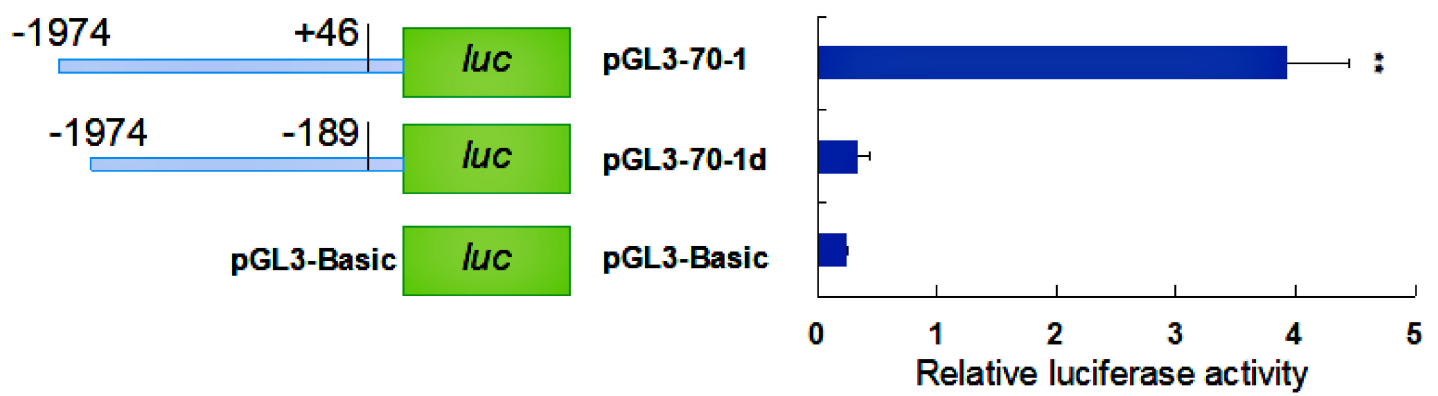

Figure 6. The relative activity of the HdHSP70 gene with and without the predicted core promoter region. The plasmid with one from -1974 to +46 containing the core promoter region was named pGL3-70-1 and the other one from -1974 to -189 lacking the core promoter region was named pGL3-70-1d. Values are means \pm SD of biological replicates $(n=3)$. The significant difference is indicated by a $\left(^{* *}\right)$ at $p<0.01$ as compared with the control (pGL3-Basic). Luc: luciferase expression plasmids.

To investigate if the HdHSP70 promoter-driven luciferase reporter gene is induced by heat shock, HEK293FT cells was exposed to high temperatures, ranging from $37^{\circ} \mathrm{C}$ to $39^{\circ} \mathrm{C}$ and also $42{ }^{\circ} \mathrm{C}$ for $40 \mathrm{~min}$, we found a significant increase in the activities of luciferase at $39^{\circ} \mathrm{C}$ and $42{ }^{\circ} \mathrm{C}$ compared to $37^{\circ} \mathrm{C}(p<0.05)$, with the highest activity being observed at $39^{\circ} \mathrm{C}$ (Figure 7$)$.

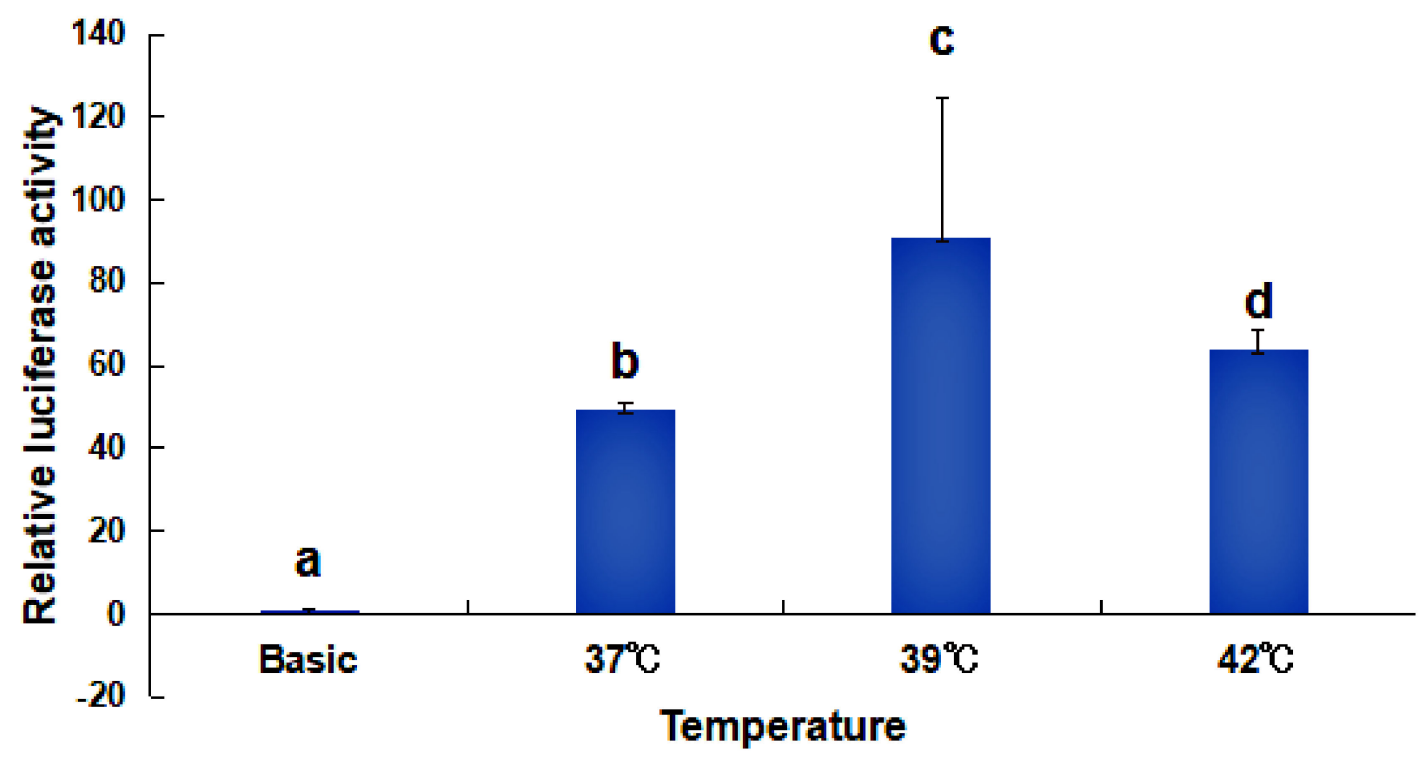

Figure 7. Changes of $\mathrm{HdHSP70}$ promoter activity in HEK293FT cells under high temperatures. The cells were exposed to high temperatures $\left(37^{\circ} \mathrm{C}, 39^{\circ} \mathrm{C}\right.$ and $\left.42^{\circ} \mathrm{C}\right)$ for $40 \mathrm{~min}$. Values are means $\pm \mathrm{SD}$ of biological replicates $(n=3)$. The different letters on the error bars indicate different significant differences, $p<0.05$.

To identify important transcription factor binding sites in the HdHSP70 promoter region, the continuous truncated promoter fragments of the HdHSP70 gene by PCR were amplified and cloned into luciferase reporter vectors. These recombinant plasmids were named pGL3-70-1, pGL3-70-2, pGL3-70-3, pGL3-70-4, pGL3-70-5, pGL3-70-6, and pGL3-70-7 and were used to transfect into HEK293FT cells. The results showed that most of luciferase recombinant plasmids, from pGL3-70-1 to pGL3-70-7 had greater activity than the control group (pGL3-Basic, $p<0.05$ ). The luciferase activity of pGL3-70-2 was significantly higher than other recombinant plasmids $(p<0.05)$, suggesting that important regulatory elements exist in the pGL3-70-1 to pGL3-70-3 regions of the HdHSP70 gene promoter (Figure 8). 


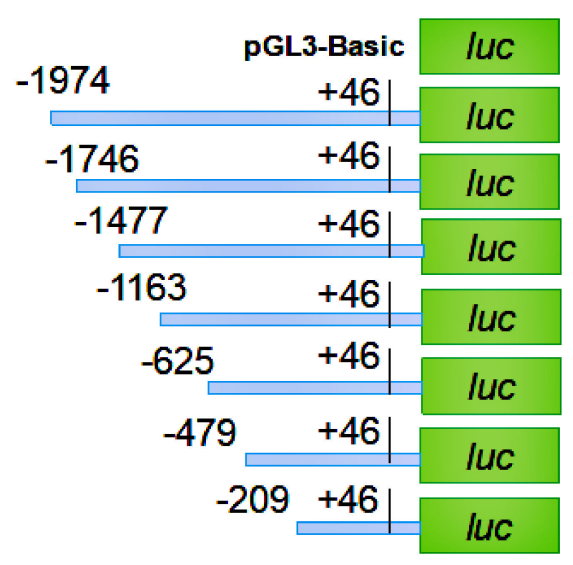

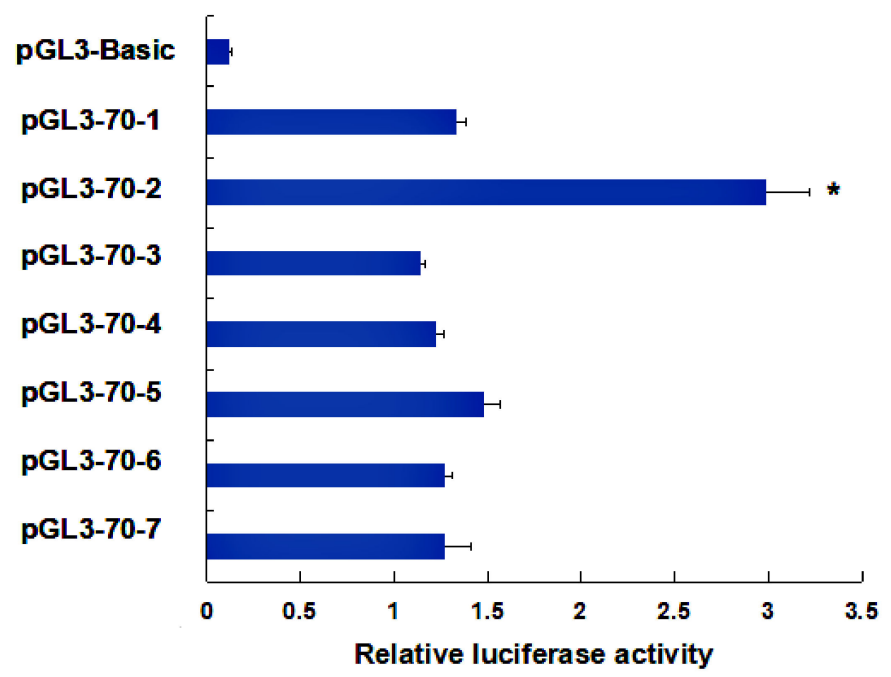

Figure 8. Activity analysis of HdHSP70 gene promoter in HEK293FT cells. Based on the length of the seven fragments, the recombinant plasmids were named pGL3-70-1, pGL3-70-2, pGL3-70-3, pGL3-70-4, pGL3-70-5, pGL3-70-6 and pGL3-70-7. The pRL-TK vector containing Renilla luciferase gene was transfected as an internal reference to correct the transfection efficiency. The pGL3-Basic plasmid was served as a negative control. The significance of luciferase activity differences was analyzed using one-way ANOVA (Analysis of Variance) test. The values were averaged from three independent replicates. Values are means \pm SD of biological replicates $(n=3)$. The significant difference between pGL3-70-2 and pGL3-70-1 or pGL3-70-3 is indicated by a $\left.{ }^{*}\right)$ at $p<0.05$. Luc: luciferase expression plasmids.

Based on the results obtained, we hope to find regulatory transcription factors from pGL3-70-1 to pGL3-70-2 and from pGL3-70-2 to pGL3-70-3, respectively. The distance between the two deletion fragments of pGL3-70-1 and pGL3-70-2 contains a sole NF-1 binding site (TGACATTTCA) in the promoter of HdHSP70. Thus, we hypothesized that NF-1 is an important transcriptional binding factor for HdHSP70. To test our hypothesis, the AC (an adenine nucleotide is followed by a cytosine nucleotide in the linear sequence of bases along its $5^{\prime} \rightarrow 3^{\prime}$ direction) of the sequence of NF- 1 binding site was mutated to CT (a cytosine nucleotide is followed by a thymine nucleotide in the linear sequence of bases along its $5^{\prime} \rightarrow 3^{\prime}$ direction), and the sequence became TGCTATTTCA instead of TGACATTTCA, and the mutant recombinant plasmid was named pGL3-NF-mut. A recombinant plasmid containing wild type of NF-1 binding site was also constructed and named pGL3-NF-wt. The luciferase activity analysis showed that in pGL3-NF-mut, luciferase activity was significantly increased compared to the same in pGL3-NF-wt $(p<0.05)$ (Figure 9). Similarly, the distance between the two deletion fragments of pGL3-70-2 and pGL3-70-3 contains a sole NF- $\mathrm{KB}$ binding site in the promoter of HdHSP70. Thus, we hypothesized that NF-kB is an important transcriptional binding factor for HdHSP70. To test our hypothesis, a recombinant plasmid containing NF-KB binding site GCTTAAGAGGAATTT was constructed and named pGL3-NK-wt. A recombinant plasmid in which GCTT was deleted to achieve a sequence AAGAGGAATTT instead of GCTTAAGAGGAATTT was constructed and named pGL3-NK-mut. The luciferase activity analysis showed that in pGL3-NK-mut, luciferase activity was significantly decreased compared to the same in pGL3-NK-wt $(p<0.05)$ (Figure 10). 


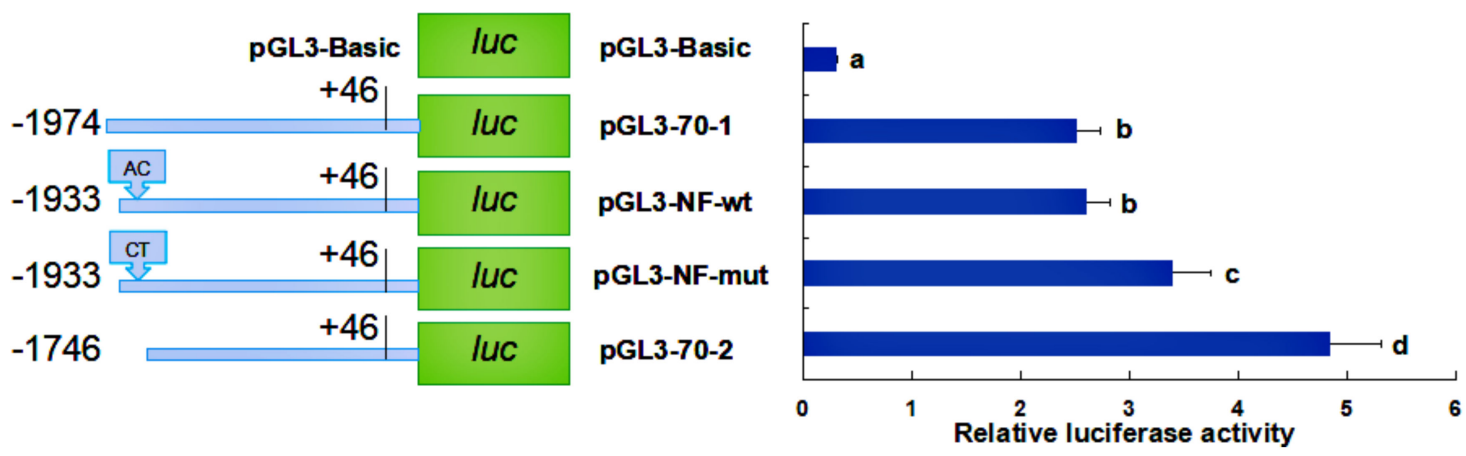

Figure 9. Activity analysis of the site-directed mutation plasmid pGL3-NF-mut. The distance between pGL3-70-1 and pGL3-70-2 contains a sole NF-1 binding site (TGACATTTCA) in the promoter of HdHSP70. In addition, the binding sites of the transcription factor NF-1 is TGACATTTCA, so the recombinant plasmid was named pGL3-NF-wt. When AC was mutated into $\mathrm{CT}$, the sequence became TGCTATTTCA, and the mutant recombinant plasmid was named pGL3-NF-mut. The pGL3-Basic plasmid was served as a negative control. Values are means \pm SD of biological replicates $(n=3)$. The different letters on the error bars represent significant differences, $p<0.05$. Luc: luciferase expression plasmids.

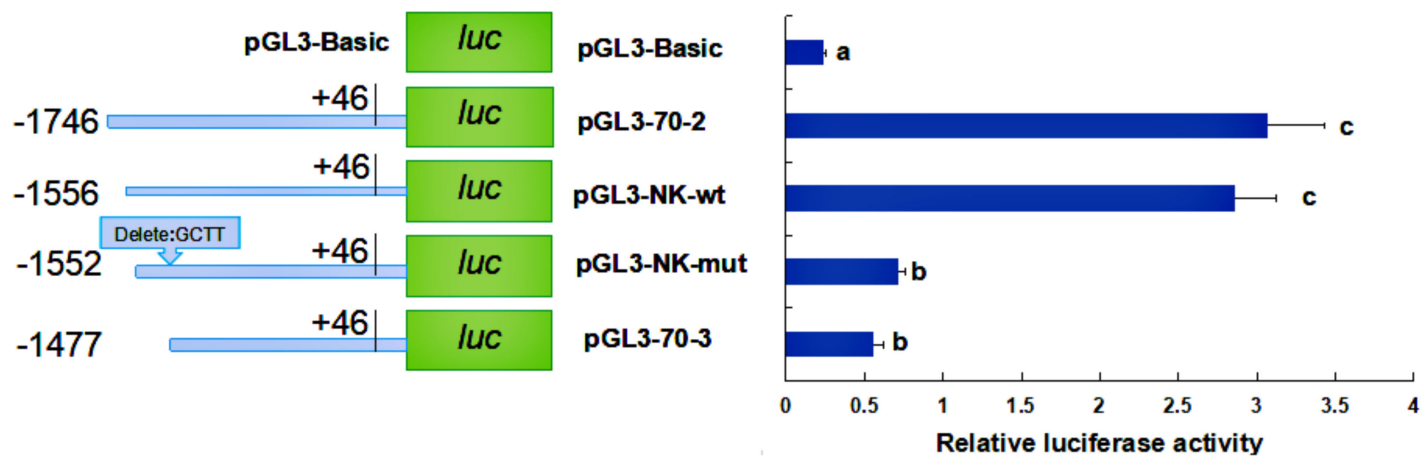

Figure 10. Activity analysis of the site-deleted mutation plasmid pGL3-NK-mut. The distance between pGL3-70-2 and pGL3-70-3 contains a sole NF- KB binding site in the promoter of HdHSP70. In addition, the binding sites of the transcription factor NF- $k B$ is GCTTAAGAGGAATTT, and the recombinant plasmid was named pGL3-NK-wt. When GCTT was deleted, the new sequence became AAGAGGAATTT, and the mutant recombinant plasmid was named pGL3-NK-mut. The pGL3-Basic plasmid was served as a negative control. Values are means \pm SD of biological replicates $(n=3)$. The different letters on the error bars represent significant differences, $p<0.05$. Luc: luciferase expression plasmids.

\section{Discussion}

A lot of evidence suggests that HSP70 is an activator of the innate immune system [41-43]. When the body is stimulated by unfavorable factors such as changes in temperature, hypoxia, and pathogenic infection [44], HSP70 can be expressed in a short time to increase the tolerance of the body to adverse factors. For example, Aleng et al. reported that non-lethal heat shock (NLHS) treatment helped Asian green mussel Perna viridis to tolerate pathogen infection [45]. Junprung et al. suggested that NLHS treatment enhanced the tolerance of Penaeus vannamei to V. parahaemolyticus infection [43]. However, the effect of HSP70 on $\mathrm{H}$. diversicolor immune function has rarely been studied. Our results provide a relevant basis for $H d H S P 70$ to involve in the heat-induced/infective immune function of $H$. diversicolor and that $H d H S P 70$ expression is regulated by related transcription factors. 


\subsection{The Expression of HdHSP70 mRNA in Different Tissues and Different Stresses}

The study of the HSP70 family has confirmed the importance of cell self-protection by controlling protein metabolism under stress conditions [24,46]. Therefore, studying the distribution of HdHSP70 mRNA in different tissues and different stresses will help us understand its stress response mechanism. According to the results of qRT-PCR, the expression of HdHSP70 gene in Hp and He was significantly different from other tissues, especially in Hp. It has been reported that Hp and He play an important role in the innate immune system in mollusks $[47,48]$. Therefore, Hp and He may be more sensitive to environmental stress than other tissues. Many studies have similar results, for example, the higher expression of the HSC70 mRNA in HP and HE of H. diversicolor [49], and higher expression of HSP70 mRNA in the blood of Oncorhynchus mykiss [50]. Norouzitallab et al. reported that the increase gradually expression of HSP70 in the mild heat stress of Artemia [41]. Junprung et al. found that NLHS could induce significant up-regulation of HSP70 gene in hemocytes of P. vannamei in 0-6 h [43].

Studies have confirmed that natural fluctuations in environmental temperature and other physical and chemical parameters can lead to the induction of cell stress responses in some mussels and marine snails, of which the HSP family plays an important role [51,52]. Tirard et al. have reported that hemocytes of the Crassostrea virginica exhibited a strong heat-shock response when undergoing a sharp rise in temperature, which characterized by enhanced synthesis of several proteins [53]. Furthermore, HSP levels are not only indicators of heat exposure. In winter, the expression level of HSP70 mRNA by Mytilus californianus was higher than in summer [54]. Encomio and Chu observed that the total amount of HSP70 in the C. virginica did not have a positive correlation with seasonal changes in temperature [55]. It has also been reported that HSP70 increased in the tolerance of P. vannamei to acute hepato-pancreatic necrosis disease (AHPND) due to V. parahaemolyticus infection [43]. These different results indicate that the expression of HSP70 is plastic, which may depend on the type of environmental stresses, intensity, and duration.

Our results showed that the relationship between HSP70 mRNA levels and elevated temperatures and V. parahaemolyticus infection was similar to these studies. Regardless of the normal or thermal stress condition in the Hp and He, the expression level of HdHSP70 in V. parahaemolyticus infection group (NE and HE group) was significantly higher than control group. In Hp, high expression of HdHSP70 occurs in HE at $4 \mathrm{~h}$ and $12 \mathrm{~h}$ and NE appears at $24 \mathrm{~h}$. In He, high expression of HdHSP70 occurs in $\mathrm{HE}$ at $12 \mathrm{~h}, 24 \mathrm{~h}$ and $48 \mathrm{~h}$ and in NE for $48 \mathrm{~h}$. Interestingly, in our experimental results, the high expression time of HdHSP70 of HE group and NE group in the Hp was obviously earlier than that in the He. In Hp, the highest expression of HdHSP70 appeared in HE at $12 \mathrm{~h}$ and in NE at $24 \mathrm{~h}$; however, in He, the highest expression of HdHSP70 appeared in HE at $24 \mathrm{~h}$ and NE at 48h. This is probably because HSP70 in the Hp responds to stress more preferentially than He. It is also possible that in different tissues, there are probably different immune regulatory mechanisms to face the body's stress. Although these immunomodulatory mechanisms are not yet clear in $H$. diversicolor at present, the fact is apparent that the increase of HSP70 mRNA expression after stress enables the cells, tissues, and even the whole organism to obtain higher and earlier anti-stress ability.

\subsection{Analysis of the 5'-Flanking Sequence of the HSP70 Gene}

CpG island is a fragment with high GC content, which is located at the $5^{\prime}$-end of the gene. It plays an important role in regulating gene expression [56,57]. The predicted CpG island is close to TSS of the HdHSP70 gene that is different from the CpG island of the HSC70 gene in H. diversicolor, which is far from TSS [49]. Studies have shown that typical CpG islands appear on or near the TSS of most genes in eukaryotes, so many studies have focused on the proximal CpG island of the promoter and found that it can initiate transcription [58]. Conversely, Sarda et al. found that the CpG island in the MethExp gene (away from the annotated TSS) has promoter-like characteristics and was involved in transcriptional regulation of genes [59]. Whether there is a difference of CpG island between HdHSP70 and HdHSC70 influences transcription level is worth exploring. 
Microsatellite DNAs or simple sequence repeats (SSRs) are formed by tandem repeats of short core sequences [60], which has become one of the hottest topics in genetics and ecology in recent years. Many studies have shown that SSR repeats appear to be a key regulatory factor in gene expression and expression levels. It has been found that some AT-rich sequence elements in the promoter region contain transcription factor binding sites, which play a significant regulatory role [61,62]. Some reports have also demonstrated that SSRs of different sizes in eukaryotic promoters can cause differential gene expression [63,64]. Shimajiri et al. found that the promoter activity of the matrix metalloproteinase-9 gene was down-regulated by shortening the (CA $)_{21}$ microsatellite sequence [65]. In addition, some genes can only be expressed in a specific number of replicates of SSR. For example, (GAA) $)_{12}$ in the E. coli lacZ gene promoter allows expression of the lacZ gene, while neither (GAA) ${ }_{14-16}$ nor (GAA) $)_{5-11}$ allow expression of this gene [66]. The $5^{\prime}$ - regulatory region of HSP70 gene contains a (TG) 39 microsatellite, which may be used to study the relationship between the number of microsatellites and the regulation of $H d H S P 70$ gene expression.

The promoter region of the HSPs gene often contain the binding sequences of a series of trans-factors that induce the basic transcription, such as SP1, CAAT (a sequence of DNA in the core promoter region of genes) and TATA boxes, and with some HSEs in their $5^{\prime}$-upstream. Zhuang et al. cloned the $5^{\prime}$-flanking regions of the $538 \mathrm{bp}$ and $305 \mathrm{bp}$ lengths of the Bombyx mori HSP70 genes and found that HSE existed in the upstream of the TATA-box sequence [67]. Kust et al. found that the $5^{\prime}$-regulatory region of the Drosophila HSP70 promoter contains 4 and 8 HSEs sequences and the promoter activation required $24 \mathrm{~h}$ after heat shock for the constructs with eight HSEs, but those with four HSEs required $48 \mathrm{~h}$ [68]. Another study showed that the promoters of HSP70 genes contain multiple copies of HSE located at variable distance 5 '-end to the TATA box, and the proximal HSE (nearest to the TATA box) is the most important in transcriptional activation of the HSP70 gene [69]. Tsutsumiishii et al. used different reporter constructs containing proximal HSE, distal HSE to identify HSE and found that proximal HSE is required for activation of the HSP70 promoter [70]. Interestingly, the distal HSE (farther away from the TATA box) in the Xenopus HSP70 gene was heat-induced in monkey COS cells [71]. However, the distal HSE of the Drosophila HSP23 gene was not heat-induced in same cells [72]. Apparently, the HSE positional relationship in the heat-inducible promoter is not absolute, but the presence of multiple HSE binding sites in most genes is significant. There are 5 HSEs in the $5^{\prime}$-regulatory region of HdHSP70 (one HSE is closer to the TATA box and the other four are farther), and their number and distribution are similar to HSE in the HSC70 gene of H. diversicolor [49]. Although there was no typical correlation between the numbers or position of HSE and the degree of heat-shock-induced expression, it is presumed that they play a regulatory role in the expression of HdHSP70 gene.

\subsection{Analysis of the Activity of the HdHSP70 Promoter}

The promoter of the HSPs gene is an inducible promoter whose activity is significantly increased under high temperature or other stress conditions [72]. Li et al. studied the heat-induced expression of human $H S P 70 B^{\prime}$ in vitro, and transfected the GFP heat-inducible expression vector $\mathrm{pHSP70B^{ \prime } - \mathrm { GFP }}$ into human breast cancer MCF-7 cells [73], and Zhuang et al. transferred into BmN cells with the 305 bp HSP70 promoter of Bombyx mori [67]. Their results showed that both luciferase activities increased significantly with increasing induction temperature, reflecting the activity of the HSP70 heat-shock promoter. In our experiment, the luciferase activity of $H d H S P 70$ was significantly increased in HEK293FT cells exposed to high-temperature stress, and the activity was highest at $39^{\circ} \mathrm{C}$, indicating that high-temperature stress will increase the activity of $H d H S P 70$ promoter. However, similar to $\mathrm{Li}$ et al. results, too high temperature $\left(42{ }^{\circ} \mathrm{C}\right)$ will lead to the decrease of the promoter activity [73].

In the process of transcriptional regulation of genes, promoters regulate the expression of genes under the synergistic action of certain positive or negative regulatory transcription factors [49]. Our experimental results showed the activity of the deletion fragment pGL3-70-2 was significantly higher than other deleted fragments. After mutation in the transcription factor binding site NF-1 between 
pGL3-70-1 and pGL3-70-2, HdHSP70 promoter activity was inhibited. On the other hand, mutation in the transcription factor binding site NF- $\mathrm{kB}$ between pGL3-70-2 and pGL3-70-3, HdHSP70 promoter activity was enhanced.

Nuclear factor-1 (NF-1) is a transcription factor that plays an important role in the process of gene expression. It can regulate the expression of various genes by combining with the specific identification sequence of the gene promoter [74]. For example, some studies have shown that NF-1 plays an important role in the transcription of type I collagen a1 chain gene and a2 chain gene. Without NF-1, transcription cannot proceed normally [75-77]. The transcription factor NF-1 plays a significant up-regulation role in the transcriptional expression of the human $\alpha 1$ collagen gene [74]. However, some studies have also found that NF-1 can up-regulate the proliferative activity of cells by inhibiting the expression of the $P 21$ gene in CDK (cyclin-dependent kinase) inhibitory proteins [78]. Similarly, Borengassar et al. studied the regulation of NF-1 on the expression of Sulfotransferase isoform 1A1 (SULT1A1) gene in breast cancer in vitro, and found that NF1A, NF1B and NF1C can down-regulate the expression of SULT1A1 [79]. In our experiment, although the NF-1 transcription factor has a certain inhibitory effect on the HdHSP70 gene, its regulation mechanism is still unclear and needs further investigation.

Nuclear factor kappa B (NF-kB) is a highly conserved multifunctional transcription factor that plays an important role in immune and inflammatory responses [80]. Its functions have been extensively studied in the regulation of immune-related genes in mammals and arthropods [81]. In mammals, NF- $\mathrm{kB}$ can regulate the expression of cytokines, cell adhesion molecules, stress response protein and other genes [82]. In the immune response of invertebrates, such as Drosophila, activation of NF- $\kappa B$ transcription factor can induce the expression of related immune genes [83]. Upon activation, NF-KB can regulate gene transcription by combining with transcription factor binding sites in promoters [84]. Ammirante et al. found that NF-KB activity could down-regulate the human HSP90 $\alpha$ gene promoter, revealing the relationship between NF- $\mathrm{kB}$ and HSP in cell defense mechanism [85]. Similarly, Zhao et al. found that NF-kB inhibits the activity of the HSC70 promoter in Litopenaeus vannamei [86]. However, Wilhide et al. found that the expression of HSP70.3 and HSP70.1 genes was significantly up-regulated by NF- $\mathrm{KB}$ when exploring the protective effect of coronary artery occlusion on the heart [87]. Zhang et al. found that NF- $\mathrm{kB}$ positively regulates the expression of molt-inhibiting hormone $(M I H)$ gene in Scylla paramamosain [88]. Similar results were obtained in our experiments: NF- $\mathrm{kB}$ has a positive regulatory effect on $\mathrm{HdHSP70}$ promoter activity. However, the specific regulation mechanism of NF-KB on HdHSP70 still needs further exploration.

\section{Materials and Methods}

\subsection{Animals and Preparation of Samples}

Adult small abalones (body length $6.00 \pm 0.50 \mathrm{~cm}$, weight $15.7 \pm 2.48 \mathrm{~g}$ ) were purchased from the Peiyang abalone farm (Xiamen, China). These abalones were fed with sea tangle once a day and maintained in recycling systems with sand-filtered seawater at temperature of $25^{\circ} \mathrm{C}$ and dissolved oxygen (DO) of $6.2 \mathrm{mg} / \mathrm{L}$ (as a normal condition, according to our previously published peer reviewed article) [38]. To accommodate experimental animals to the new environment, the abalones were kept under the normal condition for 7 days before the challenge experiments. The water temperature and DO were monitored continuously during the whole period of the experiment. In thermal stress experiment, the water temperature and DO were set at $30^{\circ} \mathrm{C}$ and $6.2 \mathrm{mg} / \mathrm{L}$ respectively [39,40].

Small abalones were randomly divided into four groups (as a different condition, according to our previously published peer reviewed article [40]): (1) two groups of animals were maintained for $96 \mathrm{~h}$ at the normal temperature $\left(25^{\circ} \mathrm{C}\right)$. After $96 \mathrm{~h}$, two groups were cultured under normal condition at $96 \mathrm{~h}$ : for the experiment group, all individuals were injected with $50 \mu \mathrm{L}$ live $V$. parahaemolyticus $\left(1.1 \times 10^{8} \mathrm{cfu} / \mathrm{mL}\right.$ in $\left.0.9 \% \mathrm{NaCl}\right)$ into the foot muscle, indicted as $\mathrm{NE}$, and for the blank group, all individuals were injected with $50 \mu \mathrm{L} 0.9 \% \mathrm{NaCl}$, indicted as $\mathrm{NB}$; (2) two groups maintained for 
$96 \mathrm{~h}$ at increased temperature $\left(30^{\circ} \mathrm{C}\right)$ for thermal stress experiment, $30^{\circ} \mathrm{C}$ was achieved by increasing from $25^{\circ} \mathrm{C}$ with $1{ }^{\circ} \mathrm{C}$ per hour according to our previous study [39]. After $96 \mathrm{~h}$, for the experiment group, all individuals were injected with $50 \mu \mathrm{L}$ live $V$. parahaemolyticus $\left(1.1 \times 10^{8} \mathrm{cfu} / \mathrm{mL}\right.$ in $0.9 \%$ $\mathrm{NaCl}$ ) into the foot muscle, indicted as $\mathrm{HE}$, and for blank group, the individuals were injected with $50 \mu \mathrm{L} 0.9 \% \mathrm{NaCl}$, indicted as HB. Hp and He were collected at 4, 12, 24 and $48 \mathrm{~h}$ after injection of live $V$. parahaemolyticus or $0.9 \% \mathrm{NaCl}$. At least six abalone's $\mathrm{Hp}$ and He were sampled at different time phases in all four groups. The details of these groups were summarized in Figure 11. Hemocytes (He) were isolated by centrifugation at $2000 \times \mathrm{g}$ for $10 \mathrm{~min}$ at $4{ }^{\circ} \mathrm{C}$ from hemolymph that was collected by cutting off the foot quickly. Subsequently, hemocytes were immediately stored in liquid nitrogen for RNA isolation and quantitative real-time PCR (qRT-PCR). At the same time, to assess HdHSP70 gene expression in different tissues, hepatopancreas ( $\mathrm{Hp})$, gills (Gi), mucous gland (Mg), digestive tract (Di), mantle $(\mathrm{Ma})$, and muscle $(\mathrm{Mu})$ were sampled and frozen into liquid nitrogen immediately for RNA extraction and qRT-PCR.
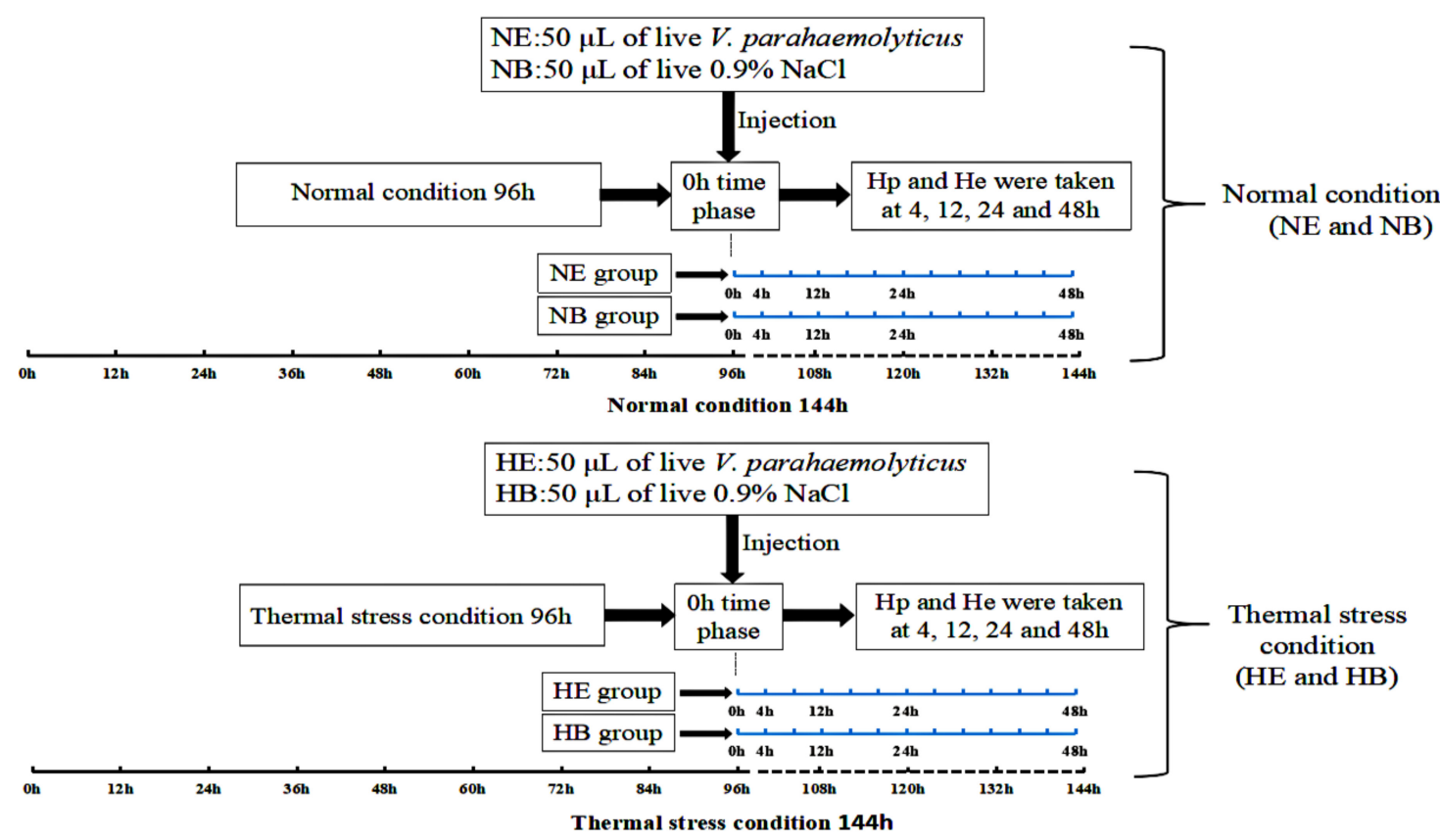

Figure 11. The frame chart of experiments in this study. Under the normal condition $\left(25^{\circ} \mathrm{C}\right)$, two groups of animals were maintained for $96 \mathrm{~h}$. After $96 \mathrm{~h}$, NE group were injected with $50 \mu \mathrm{L}$ live $V$. parahaemolyticus $\left(1.1 \times 10^{8} \mathrm{cfu} / \mathrm{mL}\right.$ in $\left.0.9 \% \mathrm{NaCl}\right)$, NB group were injected with $50 \mu \mathrm{L} 0.9 \% \mathrm{NaCl}$. Under the thermal stress condition $\left(30^{\circ} \mathrm{C}\right)$, two groups of animals were maintained for $96 \mathrm{~h}$. After $96 \mathrm{~h}$, HE group were injected with $50 \mu \mathrm{L}$ live $V$. parahaemolyticus $\left(1.1 \times 10^{8} \mathrm{cfu} / \mathrm{mL}\right.$ in $\left.0.9 \% \mathrm{NaCl}\right)$, $\mathrm{HB}$ group were injected with $50 \mu \mathrm{L} 0.9 \% \mathrm{NaCl}$. Hp and He were collected at time phases 4, 12, 24 and $48 \mathrm{~h}$. Values are means \pm SD of biological replicates $(n=6)$. HE: thermal stress and injected $V$. parahaemolyticus, HB: thermal stress and injected $\mathrm{NaCl}$. NE: normal condition and injected $V$. parahaemolyticus, NB: normal condition and injected $\mathrm{NaCl}$. Hp: hepatopancreas.

\subsection{Isolation and Reverse Transcription of Total RNA}

Total RNA was extracted from different tissues and from $\mathrm{Hp}$ and He of four groups using Total RNA Extraction Kit (Promega, Shanghai, China) according to the manufacturer's protocol. Total RNA quality was assessed by agarose gel electrophoresis and Nano Drop ND-1000. The complementary DNA (cDNA) was synthesized in $20 \mu \mathrm{L}$ reaction system including $3 \mu \mathrm{g}$ total RNA (treated with DNase I), $2 \mu \mathrm{L}$ random primers $(10 \mathrm{mM}), 4 \mu \mathrm{L} 5 \times$ First-strand Buffer, $1 \mu \mathrm{L}$ dNTP mix $(10 \mathrm{mM})$, and $1 \mu \mathrm{L}$ M-MLV reverse transcriptase $(200 \mathrm{U} / \mu \mathrm{L})$ (Promega, Shanghai, China). According to our previous 
data $[38,40,49]$, the synthesized cDNA was diluted by 10 -fold and 100 -fold and stored at $-20{ }^{\circ} \mathrm{C}$ until use.

\subsection{Analysis of HdHSP70 Gene Expression After Stresses by qRT-PCR}

qRT-PCR was carried out in LightCycler 480 Roche Realtime Thermal Cycler (Armonk, NY, USA) in accordance with the manual with a $20 \mu \mathrm{L}$ reaction volume containing $9 \mu \mathrm{L}$ of 1:100 diluted original cDNA, $10 \mu \mathrm{L}$ of $10 \times$ SYBR Green Master Mix (Promega, Shanghai, China), and $1 \mu \mathrm{L}$ of forward and reverse primer mix (10 $\mu \mathrm{M}$ each). The cycling conditions for HdHSP70 were set as follow: $1 \mathrm{~min}$ at $95^{\circ} \mathrm{C}$, then followed by 40 cycles at $95^{\circ} \mathrm{C}$ for $15 \mathrm{~s}, 60^{\circ} \mathrm{C}$ for $1 \mathrm{~min}$. The products were assessed by electrophoresis with $1 \%$ agarose gel. The housekeeping gene $\beta$-actin (Table 1 ) was used as endogenous gene, and its stability has been confirmed in our previous studies [36-38]. Melting curves were also plotted $\left(60^{\circ} \mathrm{C}-90^{\circ} \mathrm{C}\right)$ to confirm that a single PCR product was amplified. The relative quantification (RQ) of gene expression was calculated using $\Delta \Delta \mathrm{CT}$ (comparative threshold cycle) method ( $\triangle \mathrm{CT}=\mathrm{CT}$ of target gene minus $\mathrm{CT}$ of the $\beta$-actin gene, $\Delta \Delta \mathrm{CT}=\Delta \mathrm{CT}$ of any sample minus calibrator sample) and analyzed with SPSS version 20.0 (IBM, Basel, Switzerland) for One-way analysis of variance (One-way ANOVA). The $t$-test was used to determine the difference in the mean values among the treatments. The statistically significant difference was shown at $p<0.05$. 
Table 1. Primers used in this study.

\begin{tabular}{|c|c|c|c|c|c|c|}
\hline Primer Name & Start & End & Length (bp) & Primer Sequence $\left(5^{\prime} \rightarrow 3^{\prime}\right)$ & $\operatorname{Tm}\left({ }^{\circ} \mathrm{C}\right)$ & Used for \\
\hline HSP70-1 & & & & CTGAGATTTTGAAGAGAATGGC & 56.2 & \multirow{6}{*}{$\begin{array}{l}\text { Genome walking } \\
\text { and Tail-PCR }\end{array}$} \\
\hline HSP70-2 & & & & AGAGAGGGAAAGCACACGAT & 56.0 & \\
\hline HSP70-3 & & & & TATGGTGAAAGGGAGGTAATCC & 57.7 & \\
\hline HSP70-4 & & & & ATGGGGAGTGAGTCTGGTGG & 59.1 & \\
\hline HSP70-5 & & & & CAACTCCTGGCAGACTGGGGA & 64.5 & \\
\hline pGL3-70-r & & & & CCGCTCGAGTGTGTCTCCGTAGTATACAGTCGT & 56.0 & \\
\hline pGL3-70-1 & -1974 & 46 & 2020 & CGGGGTACCGAACAGCCACACTTCACTAACC & 56.5 & \multirow{12}{*}{$\begin{array}{c}\text { HSP70 promoter } \\
\text { activity }\end{array}$} \\
\hline pGL3-70-2 & -1746 & 46 & 1792 & CGGGGTACCGTCTCAAACTCCTACTTTCCTCG & 57.1 & \\
\hline pGL3-70-3 & -1477 & 46 & 1523 & CGGGGTACCTGGGGAGTGAGTCTGGTGGT & 59.5 & \\
\hline pGL3-70-4 & -1163 & 46 & 1209 & CGGGGTACCTCAGGGCAGACACCCAACAG & 61.3 & \\
\hline pGL3-70-5 & -625 & 46 & 671 & CGGGGTACCAGTTAGGAGGATACACAAAGGACA & 57.1 & \\
\hline pGL3-70-6 & -479 & 46 & 525 & CGGGGTACCAAGTAAGGGCAGGGAGCAGG & 60.9 & \\
\hline pGL3-70-7 & -209 & 46 & 255 & CGGGGTACCACTGGGCGTCTGTCTACCTT & 56.2 & \\
\hline pGL3-70-1dr & & & & CCGCTCGAGAAGGTAGACAGACGCCCAGT & 56.1 & \\
\hline P-rt-f & & & & CATAGACGAGGGCTCCATGT & 57.3 & \\
\hline P-rt-r & & & & TCATGGCTCGTGTGTTGTTG & 58.1 & \\
\hline$\beta$-actin-f & & & & CCGTGACCTTACAGACTACCT & 53.6 & \\
\hline$\beta$-actin-r & & & & TACCAGCGGATTCCATAC & 54.2 & \\
\hline
\end{tabular}

Notes: HSP70-1 to HSP70-5 was used as primer for genome walking and Tail-PCR amplification. pGL3-70-r is the shared reverse primer, and pGL3-70-1 to pGL3-70-7 represent the forward primers for PCR fragments with different length. pGL3-70-1dr is the reverse primer for amplifying the fragment from -1974 to $-189 \mathrm{bp}$ without the core promoter region. P-rt-f and P-rt-r are forward and reverse primers for qRT-PCR, and $\beta$-actin-f and $\beta$-actin-r are internal reference primers for qRT-PCR. Xho I and Kpn I restriction sites are labeled with short thin lines and protective bases are CGG/CCG). 


\subsection{Cloning and Bioinformatic Analyses of the 5'-Flanking Regions of HdHSP70 Gene}

The 5'-upstream regulatory sequences of HdHSP70 gene (GenBank accession number FJ812177.1) were isolated using the Tail-PCR and Universal Genome Walker Kit (TaKaRa, Dalian, ChinaTaKaRa, Dalian, China). The primer sequences used in this study are listed in Table 1. PCR products were purified, the possible objective DNA fragments were cloned into pMD19-T vector (TaKaRa, Dalian, China), then positive recombinant plasmids were sent to Sangon (Shanghai, China) for DNA sequencing. To predict the core promoter region and the transcriptional starting site, the online software NNPP (Rockville, MD, USA) (http:/ / www.fruitfly.org/seq_tools/promoter.html) was used with the minimum promoter score of 0.8 . The potential important transcription factor binding sites were analyzed by applying the online search software Alibaba2 (Heidelberg, Germany) (http:/ / www.gene-regulation.com/pub/programs/alibaba2/index.html) databases. The CpG island was predicted by using the MethPrimer (San Francisco, CA, USA) with default parameters (http://www.urogene.org/cgi-bin/methprimer/methprimer.cgi).

\subsection{HdHSP70 Promoter Activity in pEGFP-1 Vector}

The pEGFP-1 is a promoterless EGFP vector that can be used to monitor transcription from different promoters and promoter/enhancer combinations inserted into the MCS (multiple cloning site) located upstream of the EGFP coding sequence. To identify the promoter activity of the HdHSP70 gene, the promoter sequence of $H d H S P 70$ gene from -1974 to +46 in the $5^{\prime}$-flanking region relative to the transcription start site $(+1)$ was amplified using primers (Table 1), which contained the respective Xho I and Kpn I restriction sites and protective bases. The target PCR product was purified and ligated into the pEGFP-1 vector, which was also cut with Xho I and Kpn I. The recombinant vector was defined as pEGFP-HSP70, which was screened and sequenced for correctness. The pEGFP-1 and pEGFP-N1 plasmids were used as negative and positive controls, respectively. The promoter activity of the $5^{\prime}$-flanking region was then tested by transfection of the recombinant plasmid pEGFP-HSP70 into HEK293FT cells. The fluorescent signal of pEGFP-HSP70, pEGFP-1 and pEGFP-N1 were observed at $24 \mathrm{~h}$ post transfection under an inverted fluorescence microscope.

\subsection{Construction and Identification of Missing Fragment Expression Vector}

The backbone of the pGL3-Basic Luciferase Reporter Vectors is designed for increased expression and contains a modified coding region for firefly luciferase, which lacks eukaryotic promoter and enhancer sequences. In addition, it has been optimized for monitoring transcriptional activity in transfected eukaryotic cells. To further identify the core promoter region of the HdHSP70 gene, two constructed reporter plasmids with pGL3-70-1 from -1974 to +46 containing the core promoter region and the other pGL3-70-1d from -1974 to -189 lacking the core promoter region were prepared and transfected into HEK239FT cells. Meanwhile, the negative control pGL3-Basic was set up. The two promoters' activities were detected by luciferase activities. To investigate whether the HdHSP70 promoter-driven luciferase reporter gene is induced by heat shock, HEK293FT cells were exposed to high temperatures of $37^{\circ} \mathrm{C}$ to $39^{\circ} \mathrm{C}$ and $42{ }^{\circ} \mathrm{C}$ for $40 \mathrm{~min}$ and then their luciferase activities were detected. To analyze whether the $5^{\prime}$-upstream region of the HdHSP70 gene has regulatory effects, seven consecutive deletions from the $5^{\prime}$-flanking regions were amplified by PCR. The correct seven promoter-fragment-constructs were cut with Kpn I and Xho I and cloned into pGL3-Basic reporter vector, which was also cut with Kpn I and Xho I. Finally, seven target plasmids (pGL3-70-1, pGL3-70-2, pGL3-70-3, pGL3-70-4, pGL3-70-5, pGL3-70-6 and pGL3-70-7) were extracted and purified using EndoFree Mini Plasmid KIT II (Tiangen, Beijing, China) and transfected into HEK293FT cells to test the luciferase activity of recombinant plasmids of different lengths. 


\subsection{Mutation of Transcription Factor Binding Sites}

To investigate the function of cis-acting elements, the point mutation of the binding sites of specific transcription factors was used in this experiment. Firstly, the different fragments of $5^{\prime}$-flanking sequence of HdHSP70 gene with significantly different luciferase activities were obtained from above experiments. Secondly, the different transcription factors in these different fragments were selected. Lastly, mutations were created at binding sites of different transcription factors. In this experiment, primers containing mutated bases and Kpn I and Xho I restriction sites located at each $5^{\prime}$-end were designed for overlapping extension PCR reactions. The PCR product was cloned into the pMD19-T vector, and then the fragment was digested with Kpn I/Xho I and subcloned into the promoterless vector pGL3-Basic for transfection of HEK293FT cells.

\subsection{Transient Transfection and Activity Assays of the Luciferase Reporter Plasmids}

HEK 293FT cells were routinely cultured in DMEM high glucose medium. When the well-grown cells grew to $80 \%$, the recipient cells were inoculated into the 48 -well culture plate at a density of 1-3 $\times 10^{5}$ cells/well. According to the manufacturer's recommendations the luciferase assay was performed using a Dual-Glo luciferase assay system (Promega, Madison, WI, USA) with pRL-TK vector expressing Renilla luciferase regulated by the herpes simplex virus thymidine kinase promoter. The ratio of the target plasmid to the internal plasmid was 20:1, and the ratio of Lipofectamine 2000 to plasmid was 2.1:1. Transfection reagents and plasmids were mixed and co-transfected into the HEK293FT cell line. The pEGFP-N1 plasmid was employed as the positive controls. At $24 \mathrm{~h}$ post transfection, the cells were lysed by shaking in $60 \mu \mathrm{L}$ of lysis buffer for $15 \mathrm{~min}$ at room temperature and then transferred to a $1.5 \mathrm{~mL}$ tube. After centrifugation, $5 \mu \mathrm{L}$ of the clarified supernatant was collected into a new $1.5 \mathrm{~mL}$ tube. Firefly and Renilla luciferase activities were measured by the Dual-Luciferase ${ }^{\circledR}$ Reporter Assay System (Promega, Madison, WI, USA) at the manufacturer's protocol and chemiluminescence were read using a Varioskan ${ }^{\circledR}$ Flash (Thermo Scientific, Shanghai, China) reader, respectively. The promoter activity of each plasmid was evaluated by normalizing the average of firefly luciferase activity to the ratio of Renilla luciferase activity. All the data were obtained from three independent transfection experiments performed in triplicate.

\section{Conclusions}

In this paper, HdHSP70 was inducible by pathogenic infection, thermal stress, and combined stress, thus indicating that HdHSP70 is involved in the regulation of innate immune as well as the stress response. The promotor structure and transcriptional analysis suggested that NF-1 and NF- $\mathrm{kB}$ may be two important transcription factors, which regulate the expression of HdHSP70 gene.

Author Contributions: Y.W. and Z.Z. conceived the study and designed the experiments. Z.F. conducted the experiments and wrote the manuscript. Y.S. analyzed the data. X.Z. and Y.L. conducted the experiments. G.W. designed the experiments. Y.W. and Z.Z. checked and modified the manuscript. All authors read and approved the final manuscript.

Funding: This research was funded by National Key R\&D Program of China (grant number 2018YFD0900304), the Natural Science Foundation of China (grant number 41176152 and 41006105$)$, and International Science and Technology Cooperation and Communication Grant of Fujian Agriculture and Forestry University (grant number KXGH17019).

Acknowledgments: The work was supported by the Natural Science Foundation of China (No. 41176152, No. 41006105).

Conflicts of Interest: The authors declare no conflict of interest.

\section{References}

1. Ke, C.H.; You, W.W. Advances in genetics and breeding of Haliotis diversicolor. J. Xiamen Univ. 2011, 50, 425-430. (In Chinese) 
2. Wang, L.X.; Wang, Z.Y.; Ke, C.H.; Zhou, S.H. Genetic relationship in Halitis diversicolor. J. Xiamen Univ. 2005, 44, 98-101. (In Chinese)

3. Travers, M.A.; Basuyaux, O.; Goïc, N.L.; Huchette, S.; Nicolas, J.L.; Koken, M.; Paillard, C. Influence of temperature and spawning effort on Haliotis tuberculata mortalities caused by Vibrio harveyi: An example of emerging vibriosis linked to global warming. Glob. Chang. Biol. 2009, 15, 1365-1376. [CrossRef]

4. Shiel, B.P.; Hall, N.E.; Cooke, I.R.; Robinson, N.A.; Strugnell, J.M. Epipodial tentacle gene expression and predetermined resilience to summer mortality in the commercially important greenlip abalone, Haliotis laevigata. Mar. Biotechnol. 2017, 19, 191-205. [CrossRef]

5. Cheng, W.T.; Hsiao, I.S.; Hsu, C.H.; Chen, J.C. Change in water temperature on the immune response of Taiwan abalone Haliotis diversicolor supertexta and its susceptibility to Vibrio parahaemolyticus. Dis. Aquat. Org. 2004, 60, 157-164. [CrossRef] [PubMed]

6. Liu, P.C.; Chen, Y.C.; Huang, C.Y.; Lee, K.K. Virulence of Vibrio parahaemolyticus isolated from cultured small abalone, Haliotis diversicolor supertexta, with withering syndrome. Lett. Appl. Microbiol. 2010, 31, 433-437. [CrossRef]

7. Baruah, K.; Norouzitallab, P.; Linayati, L.; Sorgeloos, P.; Bossier, P. Reactive oxygen species generated by a heat shock protein (Hsp) inducing product contributes to Hsp70 production and Hsp70-mediated protective immunity in Artemia franciscana against pathogenic vibrios. Dev. Comp. Immunol. 2014, 46, 470-479. [CrossRef]

8. Garrido, C.; Gurbuxani, S.; Ravagnan, L.; Kroemer, G. Heat shock proteins: Endogenous modulators of apoptotic cell death. Biochem. Biophys. Res. Commun. 2001, 286, 433-442. [CrossRef]

9. Lindquist, S.; Craig, E.A. The heat-shock proteins. Ann. Rev Genet. 1988, 22, 631-677. [CrossRef]

10. Chen, T.; Cao, X. Stress for maintaining memory: HSP70 as a mobile messenger for innate and adaptive immunity. Eur. J. Immunol. 2010, 40, 1541-1544. [CrossRef]

11. Ratcliffe, M.J.H. Developmental and comparative immunology. Vet. Immunol. Immunopathol. 1993, 1, 1-3. [CrossRef]

12. Gu, J.; Huang, L.X.; Shen, Y.; Huang, L.H.; Feng, Q.L. Hsp70 and small Hsps are the major heat shock protein members involved in midgut metamorphosis in the common cutworm, Spodoptera litura. Insect Mol. Biol. 2012, 21, 535-543. [CrossRef] [PubMed]

13. Ryan, J.A.; Hightower, L.E. Stress proteins as molecular biomarkers for environmental toxicology. In Stress-Inducible Cellular Responses; Feige, U., Yahara, I., Morimoto, R.I., Polla, B.S., Eds.; Birkhäuser: Basel, Switzerland, 1996; pp. 411-424.

14. Cheng, W.J.; Li, Q.L.; Sun, Y.M.; Wang, H.M.; Li, J.B.; Zhong, J.F. The research advance of HSP70. J. Anim. Sci. Vet. Med. 2008, 27, 55-57.

15. Boorstein, W.R.; Ziegelhoffer, T.; Craig, E.A. Molecular evolution of the HSP70 multigene family. J. Mol. Evol. 1994, 38, 1-17. [CrossRef]

16. Karlin, S.; Brocchieri, L. Heat Shock Protein 70 Family: Multiple sequence comparisons, function, and evolution. J. Mol. Evol. 1998, 47, 565-577. [CrossRef] [PubMed]

17. Chuang, K.H.; Ho, S.H.; Song, Y.L. Cloning and expression analysis of heat shock cognate 70 gene promoter in tiger shrimp (Penaeus monodon). Gene 2007, 405, 10-18. [CrossRef] [PubMed]

18. Choi, B.G.; Hepat, R.; Kim, Y. RNA interference of a heat shock protein, Hsp70, loses its protection role in indirect chilling injury to the beet armyworm, Spodoptera exigua. Comp. Biochem. Physiol. Part A Mol. Integr. Physiol. 2014, 168, 90-95. [CrossRef]

19. Mahroof, R.; Zhu, K.Y.; Subramanyam, B. Changes in expression of heat shock proteins in Tribolium castaneum (Coleoptera: Tenebrionidae) in relation to developmental stage, exposure time, and temperature. Ann. Entomol. Soc. Am. 2005, 98, 100-107. [CrossRef]

20. Tsan, M.F.; Gao, B. Heat shock proteins and immune system. J. Leukoc. Biol. 2009, 85, 905-910. [CrossRef]

21. Gornati, R.; Papis, E.; Rimoldi, S.; Terova, G.; Saroglia, M.; Bernardini, G. Rearing density influences the expression of stress-related genes in sea bass (Dicentrarchus labrax, L.). Gene 2004, 341, 111-118. [CrossRef]

22. Cheng, J.; Xun, X.; Kong, Y.; Wang, S.; Yang, Z.; Li, Y.; Kong, D.; Wang, S.; Zhang, L.; Hu, X. Hsp70 gene expansions in the scallop Patinopecten yessoensis and their expression regulation after exposure to the toxic dinoflagellate Alexandrium catenella. Fish Shellfish Immunol. 2016, 58, 266-273. [CrossRef] [PubMed]

23. Wu, R.; Sun, Y.; Lei, L.M.; Xie, S.T. Molecular identification and expression of heat shock cognate 70 (HSC 70) in the pacific white shrimp Litopenaeus vannamei. Mol. Biol. 2008, 42, 234-242. [CrossRef] 
24. Wang, W.; Deng, D.F.; Riu, N.D.; Moniello, G.; Hung, S.S.O. Heat shock protein 70 (HSP70) responses in tissues of white sturgeon and green sturgeon exposed to different stressors. North Am. J. Aquac. 2013, 75, 164-169. [CrossRef]

25. Franzellitti, S.; Fabbri, E. Differential HSP70 gene expression in the Mediterranean mussel exposed to various stressors. Biochem. Biophys. Res. Commun. 2005, 336, 1157-1163. [CrossRef] [PubMed]

26. Clark, M.S.; Geissler, P.; Waller, C.; Fraser, K.P.; Barnes, D.K.; Peck, L.S. Low heat-shock thresholds in wild Antarctic inter-tidal limpets (Nacella concinna). Cell Stress Chaperones 2008, 13, 51-58. [CrossRef] [PubMed]

27. Wang, L.; Qiu, L.; Zhou, Z.; Song, L. Research progress on the mollusc immunity in China. Dev. Comp. Immunol. 2013, 39, 2-10. [CrossRef] [PubMed]

28. Xu, W.; Faisal, M. Identification of the molecules involved in zebra mussel (Dreissena polymorpha) hemocytes host defense. Comp. Biochem. Physiol Part B Biochem. Mol. Biol. 2009, 154, 143-149. [CrossRef]

29. Hao, D.Q.; Zhao, L.; Chen, L.M.; Li, W.B. Comparison and application of promoter clone methods. J. Northeast Agric. Univ. 2010, 41, 154-160. (In Chinese)

30. Hahn, S.; Young, E.T. Transcriptional regulation in Saccharomyces cerevisiae: Transcription factor regulation and function, mechanisms of initiation, and roles of activators and coactivators. Genetics 2011, 189, 705-736. [CrossRef]

31. Latchman, D.S. Transcription factors: An overview. J. Biochem. Cell Biol. 1993, 74, 417-422. [CrossRef]

32. Lee, T.I.; Young, R.A. Transcription of eukaryotic protein-coding genes. Annu. Rev. Genet. 2000, 34, 77-137. [CrossRef] [PubMed]

33. Mitchell, P.J.; Tjian, R. Transcriptional regulation in mammalian cells by sequence-specific DNA binding proteins. Science 1989, 245, 371-378. [CrossRef] [PubMed]

34. Oda, S.; Mikami, S.; Urushihara, Y.; Murata, Y.; Kamei, Y.; Deguchi, T.; Kitano, T.; Fujimori, K.E.; Yuba, S.; Todo, T. Identification of a functional medaka heat shock promoter and characterization of its ability to induce exogenous gene expression in medaka in vitro and in vivo. Zool. Sci. 2010, 27, 410-415. [CrossRef] [PubMed]

35. Stephanou, A.; Isenberg, D.A.; Nakajima, K.; Latchman, D.S. Signal transducer and activator of transcription-1 and heat shock factor-1 interact and activate the transcription of the Hsp-70 and Hsp-90beta gene promoters. J. Biol. Chem. 1999, 274, 1723-1728. [CrossRef]

36. Chen, B.; Jia, T.L.; Ma, R.H.; Zhang, B.; Kang, L. Evolution of Hsp70 gene expression: A role for changes in AT-richness within promoters. PLoS ONE 2011, 6, e20308. [CrossRef] [PubMed]

37. Sistonen, L.; Sarge, K.D.; Morimoto, R.I. Human heat shock factors 1 and 2 are differentially activated and can synergistically induce hsp70 gene transcription. Mol. Cell. Biol. 1994, 14, 2087-2099. [CrossRef] [PubMed]

38. Zhang, X.; Huang, Y.T.; Cai, X.H.; Zou, Z.H.; Wang, G.D.; Wang, S.H.; Wang, Y.L.; Zhang, Z.P. Identification and expression analysis of immune-related genes linked to Rel/NF- $\mathrm{B}$ signaling pathway under stresses and bacterial challenge from the small abalone Haliotis diversicolor. Fish Shellfish Immunol. 2014, 41, 200-208. [CrossRef]

39. Huang, Y.T.; Cai, X.H.; Zou, Z.H.; Wang, S.H.; Wang, G.D.; Wang, Y.L.; Zhang, Z.P. Molecular cloning, characterization and expression analysis of three heat shock responsive genes from Haliotis diversicolor. Fish Shellfish Immunol. 2014, 36, 590-599. [CrossRef]

40. Sun, Y.L.; Xin, Z.; Wang, G.D.; Shi, L.; Zeng, X.Y.; Wang, Y.L.; Zhang, Z.P. PI3K-AKT signaling pathway is involved in hypoxia/thermal-induced immunosuppression of small abalone Haliotis diversicolor. Fish Shellfish Immunol. 2016, 59, 492-508. [CrossRef]

41. Norouzitallab, P.; Baruah, K.; Muthappa, D.M.; Bossier, P. Non-lethal heat shock induces HSP70 and HMGB1 protein production sequentially to protect Artemia franciscana against Vibrio campbellii. Fish Shellfish Immunol. 2015, 42, 395-399. [CrossRef]

42. Sung, Y.Y.; Damme, E.J.M.V.; Sorgeloos, P.; Bossier, P. Non-lethal heat shock protects gnotobiotic Artemia franciscana larvae against virulent Vibrios. Fish Shellfish Immunol. 2007, 22, 318-326. [CrossRef] [PubMed]

43. Junprung, W.; Supungul, P.; Tassanakajon, A. HSP70 and HSP90 are involved in shrimp Penaeus vannamei tolerance to AHPND-causing strain of Vibrio parahaemolyticus after non-lethal heat shock. Fish Shellfish Immunol. 2016, 60, 237-246. [CrossRef] [PubMed]

44. Makrinos, D.L.; Bowden, T.J. Natural environmental impacts on teleost immune function. Fish Shellfish Immunol. 2016, 53, 50-57. [CrossRef] [PubMed] 
45. Aleng, N.A.; Sung, Y.Y.; Macrae, T.H.; Wahid, M.E.A. Non-lethal heat shock of the Asian green mussel, Perna viridis, promotes Hsp70 synthesis, induces thermotolerance and protects against Vibrio infection. PLoS ONE 2015, 10, e0135603. [CrossRef] [PubMed]

46. Zininga, T.; Ramatsui, L.; Shonhai, A. Heat Shock Proteins as Immunomodulants. Molecules 2018, $23,2846$. [CrossRef] [PubMed]

47. Song, X.Y.; Zhang, H.; Wang, L.L.; Zhao, J.M.; Mu, C.K.; Song, L.S.; Qiu, L.M.; Liu, X.L. A galectin with quadruple-domain from bay scallop Argopecten irradians is involved in innate immune response. Dev. Comp. Immunol. 2011, 35, 592-602. [CrossRef] [PubMed]

48. Gueguen, Y.; Cadoret, J.P.; Flament, D.; Barreauroumiguière, C.; Girardot, A.L.; Garnier, J.; Hoareau, A.; Bachère, E.; Escoubas, J.M. Immune gene discovery by expressed sequence tags generated from hemocytes of the bacteria-challenged oyster, Crassostrea gigas. Gene 2003, 303, 139-145. [CrossRef]

49. Li, Y.T.; Zhang, T.; Zhang, X.; Wang, G.D.; Wang, Y.L.; Zhang, Z.P. Heat shock cognate 70 gene in Haliotis diversicolor: Responses to pathogen infection and environmental stresses and its transcriptional regulation analysis. Cell Stress Chaperones 2017, 90,1-12. [CrossRef]

50. Currie, S.; Moyes, C.D.; Tufts, B.L. The effects of heat shock and acclimation temperature on $h s p 70$ and hsp30 mRNA expression in rainbow trout: In vivo and in vitro comparisons. J. Fish Biol. 2000, 56, 398-408. [CrossRef]

51. Hofmann, G.; Somero, G. Evidence for protein damage at environmental temperatures: Seasonal changes in levels of ubiquitin conjugates and hsp70 in the intertidal mussel Mytilus trossulus. J. Exp. Biol. 1995, 198, 1509-1518.

52. Chapple, J.P.; Smerdon, G.R.; Berry, R.J.; Hawkins, A.J.S. Seasonal changes in stress-70 protein levels reflect thermal tolerance in the marine bivalve Mytilus edulis L. J. Exp. Mar. Biol. Ecol. 1998, 229, 53-68. [CrossRef]

53. Tirard, C.T.; Grossfeld, R.M.; Levine, J.F.; Kennedy-Stoskopf, S. Effect of hyperthermia in vitro on stress protein synthesisand accumulation in oyster haemocytes. Fish Shellfish Immunol. 1995, 5, 9-25. [CrossRef]

54. Roberts, D.A.; Hofmann, G.E.; Somero, G.N. Heat-shock protein expression in Mytilus californianus: Acclimatization (seasonal and tidal-height comparisons) and acclimation effects. Biol Bull. 1997, 192, 309-320. [CrossRef] [PubMed]

55. Encomio, V.G.; Chu, F.E. Seasonal variation of heat shock protein 70 in eastern oysters (Crassostera virginica) infected with Perkinsus marinus (Dermo). J. Shellfish Res. 2007, 24, 167-175.

56. Tran, T.K.A.; Macfarlane, G.R.; Kong, R.Y.C.; O'Connor, W.A.; Yu, R.M.K. Mechanistic insights into induction of vitellogenin gene expression by estrogens in Sydney rock oysters, Saccostrea glomerata. Aquat. Toxicol. 2016, 174, 146-158. [CrossRef] [PubMed]

57. Shang, X.; Su, J.; Wan, Q.; Su, J. CpA/CpG methylation of CiMDA5 possesses tight association with the resistance against GCRV and negatively regulates mRNA expression in grass carp, Ctenopharyngodon idella. Dev. Comp. Immunol. 2015, 48, 86-94. [CrossRef] [PubMed]

58. Jones, P.A. Functions of DNA methylation: Islands, start sites, gene bodies and beyond. Nat. Rev. Genet. 2012, 13, 484-492. [CrossRef]

59. Sarda, S.; Das, A.; Vinson, C.; Hannenhalli, S. Distal CpG islands can serve as alternative promoters to transcribe genes with silenced proximal-promoters. Genome Res. 2017, 27, 553-566. [CrossRef]

60. O'Connell, M.; Wright, J.M. Microsatellite DNA in fishes. Rev. Fish Biol. Fish. 1997, 7, 331-363. [CrossRef]

61. Kube, D.; Laser, H.; Von, K.A.; Tesch, H. The AT-rich region between-54 to-66 is important for the promoter activity of interleukin-10 in Epstein-Barr virus positive Burkitt's lymphoma cells. J. Genes Immun. 1999, 1, 105-114. [CrossRef]

62. Delaney, S.K.; Orford, S.J.; Martinharris, M.; Timmis, J.N. The fiber specificity of the cotton FSltp4 gene promoter is regulated by an AT-rich promoter region and the AT-hook transcription factor GhAT1. Plant Cell Physiol. 2007, 48, 1426-1437. [CrossRef] [PubMed]

63. Hamada, H.; Seidman, M.; Howard, B.H.; Gorman, C.M. Enhanced gene expression by the poly (dT-dG). poly (dC-dA) sequence. Mol. Cell. Biol. 1984, 4, 2622-2630. [CrossRef] [PubMed]

64. Tae, H.J.; Luo, X.; Kim, K.H. Roles of CCAAT/enhancer-binding protein and its binding site on repression and derepression of acetyl-CoA carboxylase gene. J. Biological Chem. 1994, 269, 10475-10484.

65. Shimajiri, S.; Arima, N.; Tanimoto, A.; Murata, Y.; Hamada, T.; Wang, K.Y.; Sasaguri, Y. Shortened microsatellite d (CA) 21 sequence down-regulates promoter activity of matrix metalloproteinase 9 gene. FEBS Lett. 1999, 455, 70-74. [CrossRef] 
66. Li, Y.C.; Korol, A.B.; Fahima, T.; Beiles, A.; Nevo, E. Microsatellites: Genomic distribution, putative functions and mutational mechanisms: A review. Mol. Ecol. 2002, 11, 2453-2465. [CrossRef] [PubMed]

67. Zhuang, L.F.; Wei, H.; Lin, J.R.; Zhong, B.X. Identification of Bombyx mori hsp70 promoter and its function. Chin. J. Cell Biol. 2011, 33, 503-509.

68. Kust, N.; Rybalkina, E.; Mertsalov, I.; Savchenko, E.; Revishchin, A.; Pavlova, G. Functional analysis of Drosophila HSP70 promoter with different HSE numbers in human cells. PLoS ONE 2014, 9, e101994. [CrossRef]

69. Bienz, M. Transient and developmental activation of heat-shock genes. Trends Biochem. Sci. 1985, 10, 157-161. [CrossRef]

70. Tsutsumiishii, Y.; Tadokoro, K.; Hanaoka, F.; Tsuchida, N. Response of heat shock element within the human HSP70 promoter to mutated p53 genes. Cell Growth Differ. 1995, 6, 1-8.

71. Bienz, M. Xenopus $h s p 70$ genes are constitutively expressed in injected oocytes. Embo J. 1984, 3, $2477-2483$. [CrossRef]

72. Pei, H.L.; Hu, H.G.; Zhang, X.G.; Su, C.G.; Song, X.X. Cloning and functional analysis of the heat-inducible promoter AtHSP70b. Chin. Agric. Sci. Bull. 2007, 23, 82-86. (In Chinese)

73. Li, Y.Q.; Li, J.; Li, H.X.; Wang, X.F.; Zhu, Y.; Ye, F.; Zhang, Z.Z.; Ren, X.L. Construction of an HSP 70B' promoter-driven heat-inducible vectors pHSP- shTERT and its anti-proliferative effect in breast cancer MCF-7 cells. Chin. J. Cancer Biother. 2014, 21, 130-135. (In Chinese)

74. Wang, H.D.; Zheng, J.H.; Deng, C.L.; Song, N.; Wu, J.J.; Zhang, S.X.; Ding, Z.; Mao, G.Y.; Lan, G.E.; Zhao, X.B. Study of NF-1 expression in keloid. Chin. J. Aesthet. Med. 2009, 18, 497-499.

75. Anania, F.A.; Potter, J.J.; Rennietankersley, L.; Mezey, E. Effects of acetaldehyde on nuclear protein binding to the nuclear factor I consensus sequence in the alpha 2(I) collagen promoter. Hepatology 1995, 21, 1640-1648. [PubMed]

76. Chen, S.J.; Artlett, C.M.; Jimenez, S.A.; Varga, J. Modulation of human $\alpha 1$ (I) procollagen gene activity by interaction with Sp1 and Sp3 transcription factors in vitro. Gene 1998, 215, 101-110. [CrossRef]

77. Artlett, C.M.; Chen, S.J.; Varga, J.; Jimenez, S.A. Modulation of basal expression of the human $\alpha 1(\mathrm{I})$ procollagen gene (COL1A1) by tandem NF-1/Sp1 promoter elements in normal human dermal fibroblasts. Matrix Biol. 1998, 17, 425-434. [CrossRef]

78. Ouellet, S.; Vigneault, F.; Lessard, M.; Leclerc, S.; Drouin, R.; Guérin, S.L. Transcriptional regulation of the cyclin-dependent kinase inhibitor 1A (p21) gene by NFI in proliferating human cells. Nucleic Acids Res. 2006, 34, 6472-6487. [CrossRef]

79. Yao-Borengassar, A.; Rogers, L.; Raj, V.; Kadlubar, S. Abstract B23: Sulfotransferase isoform 1A1 (SULT1A1) gene expression is regulated by transcription factor NF1 in human breast cancer cell lines. Cancer Prev. Res. 2014, 5, B23. [CrossRef]

80. Pahl, H.L. Activators and target genes of Rel/NF-kB transcription factors. Oncogene 2003, 18, $6853-6866$. [CrossRef]

81. Vallabhapurapu, S.; Karin, M. Regulation and function of NF-kappaB transcription factors in the immune system. Annu. Rev. Immunol. 2009, 27, 693-733. [CrossRef]

82. Oeckinghaus, A.; Ghosh, S. The NF-кB family of transcription factors and its regulation. Cold Spring Harb. Perspect. Biol. 2009, 1, a000034. [CrossRef] [PubMed]

83. Tanji, T.; Yun, E.Y.; Ip, Y.T. Heterodimers of NF-kappaB transcription factors DIF and Relish regulate antimicrobial peptide genes in Drosophila. Proc. Natl. Acad. Sci. USA 2010, 107, 14715-14720. [CrossRef] [PubMed]

84. Greten, F.R.; Karin, M. The IKK/NF-kappaB activation pathway-a target for prevention and treatment of cancer. Cancer Lett. 2004, 206, 193-199. [CrossRef] [PubMed]

85. Ammirante, M.; Rosati, A.; Gentilella, A.; Festa, M.; Petrella, A.; Marzullo, L.; Pascale, M.; Belisario, M.A.; Leone, A.; Turco, M.C. The activity of hsp $90 \alpha$ promoter is regulated by NF-kB transcription factors. Oncogene 2008, 27, 1175-1178. [CrossRef] [PubMed]

86. Zhao, C.; Zhang, X.J.; Li, F.H.; Huan, P.; Xiang, J.H. Functional analysis of the promoter of the heat shock cognate 70 gene of the Pacific white shrimp, Litopenaeus vannamei. Fish Shellfish Immunol. 2013, 34, 397-401. [CrossRef] [PubMed] 
87. Wilhide, M.E.; Tranter, M.; Ren, X.; Chen, J.; Sartor, M.A.; Medvedovic, M.; Jones, W.K. Identification of a NF- $\mathrm{BB}$ cardioprotective gene program: NF- $\mathrm{BB}$ regulation of Hsp70.1 contributes to cardioprotection after permanent coronary occlusion. J. Mol. Cell. Cardiol. 2011, 51, 82-89. [CrossRef] [PubMed]

88. Zhang, X.; Huang, D.P.; Jia, X.W.; Zou, Z.H.; Wang, Y.L.; Zhang, Z.P. Functional analysis of the promoter of the molt-inhibiting hormone $(M I H)$ gene in mud crab Scylla paramamosain. Gener. Comp. Endocrinol. 2017, 259, 131-140. [CrossRef]

Sample Availability: Samples of $H d H S P 70$ cDNA and seven target plasmids are available from the authors.

(C) 2019 by the authors. Licensee MDPI, Basel, Switzerland. This article is an open access article distributed under the terms and conditions of the Creative Commons Attribution (CC BY) license (http:/ / creativecommons.org/licenses/by/4.0/). 